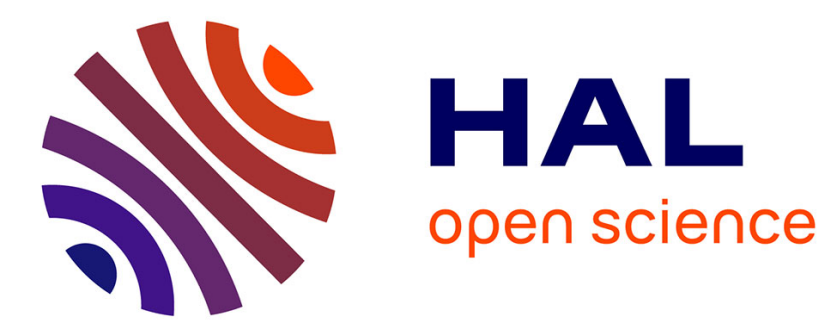

\title{
From surface fault traces to a fault growth model: the Vogar fissure swarm of the Reykjanes Peninsula, Southwest Iceland
}

\author{
Thierry Villemin, Françoise Bergerat
}

\section{To cite this version:}

Thierry Villemin, Françoise Bergerat. From surface fault traces to a fault growth model: the Vogar fissure swarm of the Reykjanes Peninsula, Southwest Iceland. Journal of Structural Geology, 2013, pp.1-35. 10.1016/j.jsg.2013.03.010 . hal-00815189

\author{
HAL Id: hal-00815189 \\ https://hal.science/hal-00815189
}

Submitted on 19 Apr 2013

HAL is a multi-disciplinary open access archive for the deposit and dissemination of scientific research documents, whether they are published or not. The documents may come from teaching and research institutions in France or abroad, or from public or private research centers.
L'archive ouverte pluridisciplinaire HAL, est destinée au dépôt et à la diffusion de documents scientifiques de niveau recherche, publiés ou non, émanant des établissements d'enseignement et de recherche français ou étrangers, des laboratoires publics ou privés. 
1 From surface fault traces to a fault growth model: the Vogar Fissure Swarm of the

2 Reykjanes Peninsula, Southwest Iceland.

3

4 Thierry Villemin ${ }^{\mathrm{a}}$, Françoise Bergerat ${ }^{\mathrm{b}}$ *

5 a EDYTEM (UMR 5204 CNRS-Université de Savoie), Campus scientifique, 73376 Le

6 Bourget du lac Cedex, France - Thierry.Villemin@univ-savoie.fr

7 b ISTeP (UMR 7193 CNRS-UPMC), Université Pierre et Marie Curie, Case 117, 4, Place

8 Jussieu, 75252 Paris Cedex 05, France - Francoise.bergerat@upmc.fr-Tel. 33144273443

9

10 Keywords

11 Icelandic rift, Fissure swarm, Normal fault growth, Remote sensing, Photogrammetric 12 techniques, Divergent plate boundary.

14 Abstract

The Vogar Fissure Swarm is one of four en-echelon fracture swarms that connect the 16 Reykjanes Ridge to the South Iceland Seismic Zone and the Western Volcanic Zone. 17 Occurring in an area of flat topography, this fissure swarm is clearly visible at the surface, where it can be seen to affect recent postglacial lavas. Using remote sensing methods to identify and measure all the faults and fractures in the swarm, combined with additional field observations and measurements, we measured 478 individual fractures, 33\% of them being

21 faults and $67 \%$ being fissures. The fracture lengths show roughly log-normal distributions.

22 Most of the individual fractures belong to 68 main composite fractures, seven of which are

23 longer than $2500 \mathrm{~m}$ and correspond to the main fault scarps of the fissure swarm. We showed 24 that these main faults are distributed along five, equally spaced zones, $500 \mathrm{~m}$ apart and a few 25 kilometers long. We drawn 71 across-strike profiles to characterize the shape of the fault 26 scarps, and 5 along-strike profiles to characterize the evolution of vertical throw along the 27 main faults. Each fault consists of a coalescence of individual segments of approximately 28 equal length. Fault throws are never larger than $10 \mathrm{~m}$ and are smallest at the junctions 29 between individual segments. Analyses of along-strike throw profiles allowed us to determine 30 the early stages of growth after coalescence. The earliest stage is characterized by an increase 
31 in the throw of the central parts of segments. This is followed by a second stage during which

32 the throw increases at the junctions between segments, progressively erasing these small33 throw zones.

\section{1. Introduction}

Iceland's neovolcanic rift zone is the surface expression of the mid-Atlantic plate boundary. It consists of three main segments, known as the Northern, Eastern and Western Volcanic Zones, which are linked to the Kolbeinsey Ridge to the north and the Reykjanes Ridge to the south (Fig. 1A). Southern Iceland's Reykjanes Peninsula lies between the Western Volcanic Zone and the offshore Reykjanes Ridge, and includes features characteristic of both divergent and transform-type plate boundaries. The general purpose of the present research is to better understand fault growth at such divergent plate boundary. The Vogar fissure swarm provides the most suitable conditions for this, as the structures are clear on postglacial lava flows and not on loose terrain with vegetation.

The volcanic zones are crossed by what are generally referred to as fissure swarms (Sæmundsson, 1978) and include central volcanoes, eruptive volcanic fissures, tension fractures, and faults. Numerous studies have examined the fracture geometry of some of Iceland's fissure swarms (Sæmundsson 1978, 1992; Guðmundsson, 1987b; Opheim and Guðmundsson, 1989; Guðmundsson and Bäckström, 2000; Tentler and Mazzoli, 2005; Friese, 2008; Hjartardottir et al., 2009), and the main features of the Vogar Fissure Swarm have been described as part of general studies of the Reykjanes Peninsula (Guðmundsson, 1980, 1986, 1987a; Grant and Kattenhorn, 2004; Clifton and Kattenhorn, 2006). Other research has shown that detailed topographical analyses of fissure swarms can be used to determine the geometry and mechanical behavior of the underlying extensional structure (Guðmundsson, 1992; Angelier et al. 1997; Dauteuil et al., 2001, Acocella et al., 2003).

Investigations of the spatial distribution of faults and fissures are essential for understanding the mechanisms underlying fault growth, and, more generally, brittle failure behaviors (Cowie et al., 1996; Torabi and Berg, 2011). Linkage and forward propagation models can be used to explain field observations. How fault segments coalesce and how this coalescence produces changes in fault architecture have been particularly well documented in different rock types and in different tectonic settings. Numerous studies have analyzed either surface (horizontal) faulting configurations (e.g., Peacock, 1991; Cartwright et al., 1995; Childs et al., 1995; Huggins et al., 1995) or vertical faulting configurations (e.g., Peacock and Zhang, 1993; Childs et al., 1996; Mansfield and Cartwright, 1996; Schöpfer et al., 2006). In 
64 fact, linkages between the different parts of normal faults occur both vertically and 65 horizontally, and on a broad range of scales. Despite all these studies, some aspects of fault

The aims of the present work were thus: (1) to produce a detailed description of the structure of the Vogar Fissure Swarm (Fig. 1C) as the basis for an analysis of its fracture style and behavior, and (2) to draw up a 3D tectonic model for the formation and growth of normal faulting in this type of fissure swarm characteristic of the Icelandic divergent boundary. To do this we combined (i) remote mapping based on geo-referencing, orthorectification, and 3D photogrammetric restitution of aerial photographs with (ii) geodetic (GPS) ground control points and (iii) field observations and measurements taken to check the remote data. The resulting accurate map of the Vogar Fissure Swarm allowed us to analyze the layout and throws of the normal faults in three dimensions and at a level of detail not previously attained for this size area. We (i) determined the type, length, and spacing of 478 individual decameter- to kilometer-scale fractures, (ii) characterized the shape of the fault scarps in 71 across-strike profiles, and (iii) measured the along-strike evolution of vertical throw along five main fault scarps.

\section{Geological setting}

The deformation in southwest Iceland is accommodated by three major structures: the Reykjanes Peninsula (RP) to the south, the Western Volcanic Zone (WVZ) to the north and the South Iceland Seismic Zone (SISZ) to the east (Fig. 1A). The direction of plate motion at the $30^{\circ}$-trending Reykjanes Ridge (offshore segment of the Mid-Atlantic Ridge) to the south of Iceland is $\mathrm{N} 104^{\circ}$ (DeMets, 1990, 1994). To the east, the SISZ is a major E-W left-lateral transform zone that connects the RP to the Eastern Volcanic Zone (EVZ). However, part of the extension continues along the WVZ. The RP is highly oblique to the direction of plate motion and geodetic studies have shown that plate spreading is accommodated both by left lateral shear (17-19 mm/yr) and by opening (7-9 mm/yr) below a locking depth of 6-9 $\mathrm{km}$ (Árnadóttir et al., 2008; Keiding et al., 2009). Leveling measurements along profiles through the RP indicate vertical displacement on normal faults of up to several millimeters over a period of about ten years, together with regional tilting (Tryggvason, 1974, 1982).

The divergent plate boundary in the RP runs for $70 \mathrm{~km}$ between Hengill volcano to the north and the tip of the peninsula to the south, and has an overall trend of $\sim 70^{\circ}$. It consists of 
four main en-echelon fissure swarms, trending $\sim 45^{\circ}$. From west to east, these swarms are the Reykjanes, Krýsuvík, Bláfjöll, and Hengill swarms (Fig. 1B).

The Reykjanes Fissure Swarm is a $35 \mathrm{~km}$ by $5-8 \mathrm{~km}$ zone of recent faulting, fissuring and volcanism that is directly connected to the offshore Reykjanes Ridge to the south. Onshore, it extends from the northern coast of the RP to its southwestern tip (Fig. 1C), cutting through postglacial basaltic pahoehoe lavas older than AD 871 and younger than $0.8 \mathrm{My}$. Its northern part, called the Vogar Fissure Swarm (VFS), is separated from its southern part by aa lavas younger than AD 871 (Jóhannesson and Sæmundsson, 2009).

The VFS (Fig. 1C) clearly shows the recent fracture pattern, allowing it to be geometrically analyzed over a wide range of scales, from minor fissures to large fault-tilted blocks.

\section{Methodology}

We used 1:25,000 scale aerial photographs obtained from "Landmælingar Íslands" (Geographic Survey of Iceland) to map the fractures of the VFS and analyze their number, length, density, and throws. These photos, which covered an area of approximately $30 \mathrm{~km}^{2}$, were digitized at a resolution of 1200 dpi (i.e. a ground resolution of $0.5 \mathrm{~m}$ ). The main data acquisition stages involved building a mosaic of aerial photographs and carrying out stereoscopic analyses of photographic pairs. Additional detailed observations and measurements were made using photographs taken from a helicopter.

We used ErMapper® software to spatially register and rectify the photographs with respect to Ground Control Points (GCP) and to a Digital Elevation Model (DEM) of the area at a resolution of one point every $90 \mathrm{~m}$. GCP coordinates were measured using GPS monofrequency Trimble receivers and GPS data were analyzed using Pathfinder Office ${ }^{\circledR}$ software. Mean calculated errors were $2-5 \mathrm{~cm}$ (horizontal) and 5-10 $\mathrm{cm}$ (vertical), so measurement uncertainties were negligible compared with the measurement errors the irregular texture of the lava flows would induce in ordinary field observations. Following orthorectification of each photograph, we created a mosaic for the whole study area (Fig. 2), which we then used as a base map for plotting the fracture traces, added using Autocad Map®.

Stereo-photographic pairs were constructed in line with the principles of parallel stereoscopy (Kasser and Egels, 2001) and using the Poivilliers software developed by Yves Egels at France's National Geographic Institute. Overlaps between two adjacent photographs 
128

129

130

131

132

133

134

135

136

137

138

139

140

141

142

143

144

145

146

147

148

149

150

151

152

153

154

155

156

157

158

159

were $\sim 60 \%$. The process involved two main steps: (i) creation of photogrammetric models and (ii) use of these models to characterize the types of fracture and to measure scarp heights, which can be considered to represent the vertical throws of the faults, as erosion is negligible in Holocene lava flows.

Each stereo pair was constructed using interior and absolute (exterior) orientation parameters. When constructing stereo pairs in this way, interior orientation requires that camera fiducial marks are positioned independently for each photograph, so the location of the principal point (projection of the perspective center on the image plane) can be calculated. We then identified several tie points and GCPs on both photographs of a stereo pair in order to simultaneously obtain relative and absolute orientations. Each point was identified by its coordinates on both the left (xl,yl) and right (xr, yr) images. This step is based on co-linearity and straight-line co-planarity conditions (Kasser and Egels, 2001). At least three GCPs spread across the entire stereo pair and at least five tie points are needed to determine absolute orientations. We used ground coordinates from GPS benchmarks as GCPs. The accuracy of our photogrammetric models enabled us to determine 3D coordinates for each point with horizontal and vertical precisions of $0.5 \mathrm{~m}$. The lava flows have such uneven surfaces that altitude differences of less than $0.5 \mathrm{~m}$ are not significant (Guðmundsson, 1992).

This process allowed us to identify and position each fracture in three dimensions, and to plot the fractures on the mosaic, using different colors to depict throw and opening characteristics (Fig. 2). The resulting fracture map was used to analyze the geometry of individual fracture traces within the VFS. We did not do any mapping in the Skógfellahraun aa lava flow (Fig. 2) because of the difficulty of following (and measuring) fracture traces in these very friable and jumbled lavas.

We used the stereo pairs to draw along-strike topographic profiles of the footwalls and hanging walls of five main fracture lines over a distance of $14 \mathrm{~km}$. We obtained 20 topographic profiles by drawing four profiles for each fracture line, two on the hanging wall and two on the footwall, at distances of $20 \mathrm{~m}$ and $40 \mathrm{~m}$ from the main scarp. We then used these topographic profiles, interpolating where necessary to obtain the points needed for calculating differences in elevation between the hanging wall and the footwall for each fracture line (see Fig. 10, section 4.6).

Moreover, punctual field observations and measurements have been carried out as control points to validate the mapping of fractures and the profile values. 
161

162

163

164

165

166

167

168

169

170

171

172

173

174

175

176

177

178

179

180

181

182

183

184

185

186

187

188

189

\section{Results}

The following descriptions of the geometrical characteristics of the fracturing are based on data obtained by analyzing aerial photographs as described above, combined with field observations and measurements.

\subsection{Fracture type terminology}

We produced maps of the VFS by tracing features from stereoscopic aerial photographs. The term "fracture" is used hereafter to refer to all types of mechanical discontinuity with a tectonic origin. We differentiated two types of fracture, those with vertical throw, referred to as normal faults, and those without vertical throw (or with vertical throw smaller than $0.5 \mathrm{~m}$ which corresponds to the accuracy obtained by the photogrammetric model), referred to as fissures. Some normal faults were open, others were not (Fig. 6). The normal faults in the VFS are actually vertical faults with both vertical displacement and dilation (Fig. 5). The Icelandic names for the main fault scarps, which also have a significant dilation component, end in "gjá" (Fig. 2), which means gap. These faults become true normal faults (shear) at depth (e.g., Angelier et al., 1997).

We refer to fractures that can be traced continuously as "individual fractures". Individual fractures commonly concentrate in fracture strips that may be discontinuous and are of varying lengths. Most fracture strips, which we refer to as "main composite fractures" (Fig. 3), are composed of several aligned individual fractures, generally including both fissures and faults (Fig. 2). For mapping purposes, we considered parallel main composite fractures to be separate if they are more than $125 \mathrm{~m}$ apart and aligned main composite fractures to be separate if they are more than $250 \mathrm{~m}$ apart.

One difficulty with this type of mapping is the difference between the scale of the photographs and the scale of the map. At the scale of the photographs used for our study, two small lines close together may be indistinguishable and appear as a single line, whereas they would appear as two separate lines on a more detailed photograph or in the field. In addition, some large fracture lines may be quite thick due to the coalescence of several individual but indistinguishable fractures.

4.2 Number of fractures and organization of the network 
We mapped 478 individual fractures (a few were only partially mapped because of the presence of the aa lava flow) in the study area (Fig. 2), 33\% of which are normal faults and $67 \%$ are fissures. Most belong to the 68 main composite fractures (Fig. 3), seven of which are more than $2500 \mathrm{~m}$ long and correspond to the main fault scarps of the fissure swarm (Fig. 4).

Except close to the Skógfellahraun aa lava flow, the main composite fractures in the western part of the VFS are composed mostly of fissures, whereas those in its eastern part are composed mostly of normal faults. The VFS is $\sim 10 \mathrm{~km}$ long, measured from the aa lava flow to its northeastern tip, and tapers from $\sim 4.5 \mathrm{~km}$ wide close to the aa lava flow to $\sim 3 \mathrm{~km}$ wide at its northeastern tip.

The western edge of the VFS is formed by a major, east-facing normal fault, called Hrafnagjá (Fig. 2; R16 in Fig. 3), whereas its eastern edge is formed by a series of open fissures, called Brunnastaðaselsgjá (Fig. 2; R66-67 in Fig. 3). The area between these two boundaries contains five major west-facing normal faults in a step pattern (Fig. 2). The easternmost major normal fault scarp is called Grindavikurgjá (Fig. 2; R59 in Fig. 3). Individual fracture strikes (fissures and faults), based on their mean linear orientation weighted by the length of each fracture segment, are between $\mathrm{N} 30^{\circ} \mathrm{E}$ and $\mathrm{N} 70^{\circ} \mathrm{E}$, with a mean strike of N55-60 E (Fig. 3).

\subsection{Length and density}

The main composite fractures are between $250 \mathrm{~m}$ and $5.6 \mathrm{~km}$ long (Fig. $7 \mathrm{C}$ ). Individual faults are between 34 and $1288 \mathrm{~m}$ long (mean length $229 \mathrm{~m}$ ). Individual fissures have a comparable minimum length $(23 \mathrm{~m})$ but maximum and average lengths are significantly shorter (545 $\mathrm{m}$ and $139 \mathrm{~m}$, respectively). Because the aa lava flows (southwestern part of Fig. 2) prevented us fully mapping a crucial part of the faults, their mean and maximum lengths were almost certainly underestimated. This is only a minor problem for the fissuring. However, some of the shortest fissures $(<10 \mathrm{~m})$ are probably masked by soil and grass, so this class is likely to be under-represented. What is more, these small fissures are similar in size to non-tectonic, cooling fractures in the lavas, so it was not always possible to measure them.

The length distributions of all the sets of fractures (Fig. 7 A and B) show roughly lognormal distributions ("heavy tail" type); therefore, the average length is not characteristic. Consequently, the classes with the highest frequencies are [75-100 m] for the faults and [50$100 \mathrm{~m}$ ] for the fissures. 
The cumulative lengths of all the fractures mapped were $44.9 \mathrm{~km}$ for the fissures and $35.7 \mathrm{~km}$ for the faults, which gives fracture densities for the area affected by faulting of 1.45 $\mathrm{m} / \mathrm{m}^{2}$ and $1.15 \mathrm{~m} / \mathrm{m}^{2}$, respectively.

\subsection{Spacing}

We measured the spacing between the fractures in the VFS along profiles perpendicular to the maximum frequency directions indicated by the rose diagrams (Fig. 3). Profile lengths (distance between most northwesterly and most southeasterly fractures) were between $1700 \mathrm{~m}$ and $4100 \mathrm{~m}$. The linear density of fractures (number of fractures per unit length) depends on the type of fracture:

- The density of the fissures is extremely variable, depending on where the crosssection was taken. The spacing distribution shows modes at $75 \mathrm{~m}, 225 \mathrm{~m}$, and $450 \mathrm{~m}$ (Fig. 8). There are probably modes at other multiples but these modes are difficult to determine due to the limited number of sampling values. These multiples result from the non-persistence of the fissures.

- The spacing distribution for all the individual fractures (faults and fissures) also shows modes at $75 \mathrm{~m}, 225 \mathrm{~m}$, and $450 \mathrm{~m}$ (Fig. 8). Some multiples may be less visible because fractures do not necessarily extend across the entire study area. Fissures linking two segments of a fault, thereby making the combined fissure longer, are very common.

- The spacing distribution of the composite fractures shows only two modes, at $225 \mathrm{~m}$ and $450 \mathrm{~m}$ (Fig. 8). The mode at $75 \mathrm{~m}$ is not present because fractures that are less than $125 \mathrm{~m}$ apart were shown by a single line when we drew the composite fractures map.

The three modes noted above can be seen clearly in Figures 2 and 3. Their significance is discussed in section 5 .

\subsection{Topography of the fissure swarm and across-strike throws}

Using the automatic protocol described in section 3, we drew 71 across-strike profiles through the entire fissure swarm (numbered 0-70 in Fig. 3). Figure 9 shows ten characteristic profiles. We calculated elevations every meter along each profile. Outliers were removed from the raw results according to two criteria. First, we removed outliers for which the value of the local correlation parameter between the two images for each point was less than 0.5. Second, we used a moving average filter on the nearest 24 points to remove elevations that differed by more than $5 \mathrm{~m}$. Even after this filtering, the elevation signal was still quite noisy. 
253 As the amplitude of the noise was around $1 \mathrm{~m}$, some normal faults with vertical throws of less 254 than $2 \mathrm{~m}$ may not have been distinguishable from the background noise. Taking into account 255 the uncertainties of the calculation method, we obtained a mean throw of 8-10 $\mathrm{m}$ for the main 256 faults (Fig. 9).

257

258 259

In the south of the network, the profiles clearly show that the lava flows dip gently $(\sim 3 \%)$ to the NW. This surface dip decreases progressively towards the north of the network.

Many faults display an obvious bulge on the surface of the lavas on the upthrown side $\sim 50 \mathrm{~m}$ from the fault scarp (e.g., R16 in Fig. 9 and detail in Fig. 9A and 9B).

In the south (sections 0-40, Fig. 3), the entire fissure swarm has a graben structure, bounded to the northwest by the east-facing Hrafnagjá normal fault (R16). In places, this large fault is associated with a secondary normal fault (e.g., R21 on profile 23, Fig. 9). To the southeast, the graben is bounded by the west-facing Grindavikurgjá normal fault (R59. This fault is not shown on the across-strike profiles because of correlation difficulties during the automatic plotting due to the location of this fault on the edge of the photographs). Faulting deformation between the two boundary faults is mainly accommodated by west-dipping normal faults, especially R24, R28, R38 and R55 in the southern part of the fissure swarm (Fig. 9). These sub-parallel normal fault scarps form a step pattern that is characteristic of the southern part of the VFS (see also Fig. 4).

The pattern in the northern part of the VFS is slightly different, as there is no equivalent of the Hrafnagja fault, and the western part of the network is composed mostly of fissures and minor faults. Consequently, the general structure changes to a hemi-graben, bounded to the southeast by two major normal faults (Klefgjá and Grindavikurgjá, R48 and R59, Fig. 9)

Some scarps along a single fault vary in shape. Generally, faults at the surface of the VFS are characterized by a near-vertical fault plane (e.g., R16 A in Fig. 9, and Fig. 5) but in some places the fault plane is flanked by a narrow monocline that, on the scale of our acrossstrike profiles, appears as a smooth bulge (e.g., compare R28 D and C in Fig. 9; see also Grant and Kattenhorn, 2004).

In this study, we decided not to focus on fault width (opening) for two reasons. (i) The methodology we used did not allow us to measure small widths, thereby precluding an exhaustive analysis. (ii) The true width is often less than the measured width due to the existence of graben-like structures. Despite the uncertainties caused by this overestimation of 
285 some of the widths, Guðmundsson (1987a) produced some accurate width measurements in 286 the VFS (1076 points measured) along six main fractures (R16, R24, R28, R38, R55 and R67

287 in the present study). He obtained a mean width for all the points measured of $0.6 \mathrm{~m}$ and an

288 289 290 291 292 293 294 295 296 297 298 299 300 301 302 absolute maximum width for a single fracture of $7.5 \mathrm{~m}$.

4.6 Changes in along-strike fault throws for the main composite fractures

We also produced automatic plots of along-strike profiles (see section 3) for five main composite fractures: the east-facing fracture (R16) that forms the western boundary of the VFS and four west-facing fractures (R24, R28, R38 and R48) within the fissure swarm (see Fig. 3 for locations). For each main composite fracture, we started with the central trace (axis of the fractured strip) and calculated two sets of two parallel traces, $20 \mathrm{~m}$ and $40 \mathrm{~m}$ from the main scarp, on the hanging wall and on the footwall, respectively. The mean distance between points was $\sim 5 \mathrm{~m}$. We then used the automatic image correlator to calculate the elevation of each point on all the traces.

Each of the four profiles for a given fracture has the same number of points. The four points with the same index on each profile represent a cross-section of the fracture and the differences in their elevations correspond to the vertical throw at distances of $20 \mathrm{~m}$ and $40 \mathrm{~m}$ from the main scarp. The profiles in Figure 10 show along-strike variations in these differences, that is, changes in the vertical throw.

Main composite fracture R16 (Hrafnagjá) is fully visible over a distance of $2500 \mathrm{~m}$. The profiles show that the throw is greatest in the central part of the fault and decreases towards its tips. This fault forms the western boundary of the VFS. Its maximum throw is $\sim 10$ m.

The other four normal main composite fractures we analyzed are located between the two main boundary faults and are all west facing. They range in length from $2800 \mathrm{~m}$ to 5400 $\mathrm{m}$, but the Skógfellahraun aa lava flow covers the southwestern ends of three of these fractures $(\mathrm{R} 24, \mathrm{R} 28, \mathrm{R} 38)$.

Main composite fracture R48 (Kvelfgjá) is $5400 \mathrm{~m}$ long and is visible in its entirety. Its profile consists of three similar, 1500-2000 m long segments, each of which is similar in size and shape to fault R16. Each segment has a mean maximum throw of 8-10 $\mathrm{m}$ in its central part. This throw decreases to zero at the segment tips. A second periodicity, with an amplitude of 2-4 m, modulates the profile of each segment every $250-500 \mathrm{~m}$. 
Main composite fracture R38 is visible over a distance of $\sim 2800 \mathrm{~m}$. It has a maximum

317 throw of $11.5 \mathrm{~m}$ and the throw decreases towards the northeast. The throw decreases $\sim 1000 \mathrm{~m}$

318 from the trace, corresponding to the junction with another main composite fracture (R36 in 319 Fig. 3 and Fig. 11). To the southeast, fractures R36 and R38 are parallel to each other and each fracture probably accommodates part of the deformation.

Main composite fracture R28 is $3500 \mathrm{~m}$ long and has a maximum throw of $\sim 10 \mathrm{~m}$. As for main composite fracture $\mathrm{R} 48$, the profile is modulated by a $\sim 500-\mathrm{m}$ periodicity with an amplitude of $\sim 5 \mathrm{~m}$. The throw decreases in four places along the profile where the fracture is mostly composed of fissures, rather than normal faults.

Main composite fracture R24 is $3000 \mathrm{~m}$ long. Again, it has a maximum throw of $\sim 10$ $\mathrm{m}$ but there is no variation in the throw along a significant part of the profile. Then, the throw decreases steadily to the northwest over the last $500 \mathrm{~m}$.

Compared with the throw profiles for complete fractures R16 and R48, it is evident that the southeastward decrease in throw is missing from main composite fractures R24, R28 and R38. This decrease probably occurs in the part of the fractures in the aa lava flow. The total length of these faults could not be measured.

In general, the throws calculated from the profiles $20-\mathrm{m}$ and $40-\mathrm{m}$ from the main scarp have very similar shapes along the main composite fractures. The $20-\mathrm{m}$ and $40-\mathrm{m}$ throw profiles for R28 and R38 are almost identical. The forms of the $20-\mathrm{m}$ and $40-\mathrm{m}$ profiles for R48 are very similar, even in their minor variations (small peaks and troughs). The only difference is the throw itself, as the throw $40 \mathrm{~m}$ from the main scarp is systematically smaller (by 2-3 $\mathrm{m}$ on average) than the throw $20 \mathrm{~m}$ from the main scarp. The differences in the R16 and R24 profiles are greater, not only because the $40 \mathrm{~m}$ profile (for R24) has a systematically smaller throw, but also because there are discrepancies between peaks and troughs $(1.5 \mathrm{~km}$ and $2 \mathrm{~km}$ from the southwestern tip for R16, and $0.5 \mathrm{~km}$ and $1.3 \mathrm{~km}$ from the southwestern tip for R24). The differences between the $20-\mathrm{m}$ and $40-\mathrm{m}$ profiles are mainly due to the lava flow almost systematically sticking up slightly on the upthrown side close to the fault scarp (Fig. 9). Local discrepancies, such as those shown by profiles R16 and R24, are due to the presence of lava swells of volcanic origin.

\subsection{The linkage zones}

The main composite faults are composed of alignments of several individual fractures, presenting different types of linkage at the surface. There are two main types of linkage 
pattern: (i) a non-overlapping pattern with aligned or non-aligned segments, and (ii) an overlapping pattern with fault segments that curve at their tips. The linkage of smaller segments into larger segments allows the growing of faults and depend in detail of the distances between their nearby tips relative to the segment lengths (Guðmundsson, 2011).

Although some neighboring aligned segments tend to propagate toward each other (Fig. 12a) and a number of non-aligned segments are linked by en echelon or oblique fractures that develop between fracture tips (Fig. 12b), most linkages form overlap patterns. We noted three types of overlap feature. In some overlapping segments, the tips of one segment propagate to the sidewall of another segment along a curved path (Fig. 12c). In other overlapping segments, parallel en-echelon fractures develop in the linkage zone (Fig. 12f). The final type consists of parallel fault segments that overlap over a long distance (Fig. 12e). Some linkage zones are complex and can include, for example, oblique and parallel fractures (Fig. 12g) or a horsetail feature (Fig. 12d, h).

In general, linkage zones connect the hanging wall of one fault to the footwall of another fault and transfer the displacement from one fault to the other. For both overlapping and non-overlapping pattterns, open fractures can develop in the linkage zone (Fig. 2, Fig. 12). Similar intermediate (or mixed) patterns to the ones we found in the VFS have also been described in other Icelandic fissure swarms (Guðmundsson, 1987a, b; Acocella et al., 2000; Grant and Kattenhorn, 2004; Tentler, 2005; Tentler and Mazzoli, 2005; Friese, 2008).

Topologically, junctions between fracture traces can be described as immature and mature. In the immature state, it is possible to pass from one side of a fracture to the other without crossing any visible fissure or fault. In the mature state, the two main segments are completely connected and the two sides of the fault are totally separated; hence, fragmentation is complete (Fig 13). Immature junctions are quite frequent along the main composite fractures of the VFS.

\section{Discussion: formation and growth of fissures and normal faults}

In the VFS, the spatial distribution of faults and fissures, as well as the changes in fault throws, allow investigating linkage and forward propagation models both vertically and horizontally. They permit to highlight the process of fault segments coalescence and the resulting changes in fault architecture.

\subsection{Surface deformation and structure at depth}


In the Icelandic crust, magma intrusion at depth is generally agreed to have a major effect on the development of tectonic structures (e.g., Angelier et al., 1997). However, how normal faults grow vertically is an important unanswered question. Evidence provided by combining seismicity and magma accumulation data suggests that most normal faulting occurs at depths of 1-5 km (Einarsson, 1991; Hreinsdóttir et al., 2001). A number of models favor upward propagation from depth (Grant and Kattenhorn, 2004; Tentler, 2005), whereas others promote downward propagation from the surface (Acocella et al., 2003). Others still advocate sub-simultaneous downward and upward propagation (Guðmundsson, 1992; Martel and Langley, 2006).

It has often been assumed that a single shear zone will usually be unable to grow in its own plane and develop into a normal fault (e.g., Scholz, 2002). Guðmundsson (1992) suggested two mechanisms for normal fault initiation: (i) nucleation from large-scale tension fractures originating at the surface and propagating to significant crustal depths, and (ii) nucleation on sets of en-echelon joints when lava flows become tilted. Guðmundsson maintains that these two mechanisms can occur concurrently, with the upper part of a fault nucleating on a large-scale tension fracture and the lower part nucleating on a set of inclined joints. He also suggests that large-scale tension fractures change into normal faults when they reach a critical depth that partly depends on the tensile strength of the host rock. Thus, a mean tensile strength of $3 \mathrm{MPa}$ (Haimson and Rummel, 1982) corresponds to a change at a crustal depth of $\sim 0.5 \mathrm{~km}$. The critical crustal depth at which inclined joints start to link up into normal faults, taking into account the associated friction, is $\sim 0.8 \mathrm{~km}$, and the process is common at $\sim 1.5 \mathrm{~km}$ (Guðmundsson, 1992). Given these two nucleation zones, Guðmundsson concludes that normal faulting starts to nucleate at crustal depths of $0.5-1.5 \mathrm{~km}$.

Following studies of the Krafla fissure swarm in northeast Iceland, Angelier et al. (1997) and Dauteuil et al. (2001) put forward a comparable model to Guðmundsson's for the relationships between open fracture geometry observed at the surface and normal fault dip inferred at depth. In this model, normal shear also plays a major role at intermediate depths in the upper brittle crust and normal faulting occurs along planes with a mean dip of $60-75^{\circ}$ at a crustal depth of $\sim 1 \mathrm{~km}$. No hypotheses for the growth mechanism were put forward.

Many studies have compared dike and fissure swarms, suggesting or refuting strong links between faults and fissures at the surface of active zones and deep dyke swarms (Helgason and Zentilli, 1985; Forslund and Guðmundsson, 1991; Guðmundsson, 1995a, b, 2003; Tentler, 2005; Paquet et al, 2007). Some authors (e.g., Rowland et al., 2007, in the Afar 
413 rift) assume (i) that normal faults are initiated or reactivated ahead of and above propagating

414 dyke and (ii) that preexisting subvertical cooling joints are reactivated as opening mode

415 fissures above the upper tip line of the normal faults. In such case the horizontal segmentation

416 of the main fault traces observed every 500-1500 $\mathrm{m}$ in our study (Fig. 10) could have

417 originated either via irregularities in the shape of the dike or via a segmentation of the dike

418 itself, which is a common feature in dike patterns (e.g., Guðmundsson, 2002). However, other

419 authors, based on field comparisons between dyke swarms and fault patterns in the eroded

420 palaeo-rift zones, demonstrated that the number of dykes by far exceeds the number of normal

421 faults in the same sections and even that where the dyke frequency was high, the fault

422 frequency was low (e.g., Forslund and Guðmundsson, 1991; Guðmundsson, 2003; Paquet et

423 al., 2007).

4245.2 Segmentation and changes in the throw and length of the fault traces

425 Cowie and Roberts' (2001) conceptual model of fault growth shows how a set of faults 426 connected at their tips evolves into a single fracture. Applied to the longitudinal profiles 427 shown in Figure 10, this model can be used to interpret the different stages we observed.

428 Cowie and Roberts distinguish two main stages (Fig. 14) in the growth of faults: a first stage 429 of isolated growth during which the throw increases moderately compared to the length, 430 followed by a second stage, when the segments are connected, during which there is a large 431 increase in the throw but only a small (or no) increase in length.

432 Cowie and Roberts (2001) identified two ways in which this second stage can proceed, 433 depending on whether or not the faults are strongly interconnected. When the links between 434 the faults are weak, the junctions between the segments become complete at the end of the 435 process, after the central parts have stopped growing. When the links between the faults are 436 strong, the throw gradually increases everywhere and the distinctions between the segments 437 gradually disappear. Our data show situations that may indicate a third, intermediate way for 438 this stage to proceed (Fig. 14). Once the segments are connected, we observed an initial step 439 (P1) during which the throw increases more in the central part of the segments than at the 440 junctions, where the throw remains small. This is followed by a second step (P2) during 441 which the throw differences at the junctions disappear.

442 Considered as a whole, R48 (Fig. 10) is an example of a fault at the end of stage 1 443 (Fig. 14), at which point the three segments are connected. In the following step, the throw of 444 the central segment should increase more than the throw in the other two segments. Finally, 
445 the differences in the throws of the segments should decrease until the fault achieves an 446 elliptical profile encompassing the three segments.

447 Analysis of the individual segments of faults R28 and R48 (Fig. 10) suggests that the

448

449

450

451

452

453

454 process is more advanced than in the case of fault R48 taken as a whole. For all the segments, the throw differences at the tips of the initial segments are being reduced and the general profile is elliptical. It should be noted that the initial segments of fault R48 are $\sim 250 \mathrm{~m}$ long, whereas the typical length of the segments of R28 is $500 \mathrm{~m}$.

According to the conceptual model, fault R16 corresponds to the final stage in the process, when any individual segments that existed at the beginning of fault development have become indistinguishable.

\subsection{Limitation of the throw and maximum throw/length ratio}

The throws we measured in the VFS are significantly smaller than the throws measured in other Icelandic fissure swarms in lava flows of comparable age (Opheim and Guðmundsson, 1989; Dauteuil et al. 2001; Tentler and Mazzoli, 2005, Sonnette et al., 2010). In addition, maximum throws in the VFS are very similar between the different faults, often $\sim 10 \mathrm{~m}$. In other areas, maximum throws have been found to be related to the length of the faults by a power law (Sonnette et al., 2010).

Compared with previously published data (Gupta and Scholz, 2000), the maximum throw/fault-length ratio is small. Considering the $2-\mathrm{km}$ segments along fault R48 to be single faults gives a maximum throw/fault-length ratio of 0.005 , which is four times smaller than the mean ratio reported by Gupta and Scholz (2000). Consequently, the throws of the segments we measured are likely to increase without the segments necessarily increasing in length.

\subsection{Interaction and linkage of fissures and normal faults}

As mentioned in section 4.7, interaction and linkage zones occur in all Icelandic fissure swarms. Linkage zones have been described in similar basaltic rocks in other geodynamic contexts, such as Kilauea Volcano in Hawaii (Peacock and Parfitt, 2002; Martell and Langley, 2006), as well as in many other geological settings and rock types, especially since the early 1990s (e.g., Morley et al., 1990; dePolo et al., 1991; Peacock and Sanderson, 1991; Anders and Schlische, 1994; Gupta and Scholz, 2000; Marchal et al., 2003).

In the case of the VFS, most of the links between faults are marked by an overlap zone, with direct connections between segments occurring in only a few cases of closely 
476

477

478

479

480

481

482

aligned segments (e.g., Fig. 12b). As described in section 4.7, most of the VFS links are of immature type (connection not complete at the surface). Detailed examination of the topology of overlapping areas reveals a predominance of left stepping en-echelon ruptures. This may indicate a small strike-slip component in addition to the main normal movement, which is consistent with the general behavior of the area as a large, left-lateral shear zone, either partitioned into NE-SW en-echelon fracture zones (Clifton et al., 2003), or resembling a transtensional segmented transform, as suggested by Geoffroy et al. (2008).

\subsection{Spacing of main composite fractures and thickness of layers}

It should be noted that the general structure of the VFS is not that of a typical graben. The structure is not axially symmetrical, as the front of the faults in the southeast is not opposite the front of the faults in the northwest, except in the case of fault R16 (Fig. 2 and 9). The cross-sections (Fig. 9) show four or five major faults, and the boundary and central faults have similar throws. The spacing of parallel main composite fractures contains at least two modes at $225 \mathrm{~m}$ and $450 \mathrm{~m}$ (Fig. 8). It should be noted that spacing of large fault zones in Holocene Icelandic fissure swarms is very variable (e.g., Guðmundsson, 1987a,b; Opheim and Guðmundsson, 1989), suggesting that the fault spacing may change during the lifetime of a fissure swarm (Forslund and Guðmundsson, 1991).

The relationship between the spacing of the fracture zones and the thickness of the brittle behavior levels has already been noted (e.g., Bai and Pollard, 2000; Ackermann et al., 2001). Seismicity in our study area appears to be restricted to depths of less than 7-8 km, with most earthquakes occurring at 4-6 km (Keiding et al., 2008). These values are too high to be related directly to the observed spacing; however, they are similar to the total width of the fissure swarm.

Grant and Kattenhorn (2004) modeled normal faulting ending at depths of 250 and $500 \mathrm{~m}$, and extending to the surface along vertical fractures. They interpreted these structures as ancient faults affecting deep layers that have subsequently been covered by younger lava flows. Reactivation of these faults could lead to the development of vertical extensions. Grant and Kattenhorn noted the presence of major discontinuities at depths of 250 and $500 \mathrm{~m}$, which could be the cause of mechanical decoupling. Another possibility, related to the potential control of the geometry and development of the fault patterns by dykes is that the spacing of the major fault zones reflects the spacing between the underlying dikes. This is however unlikely in so far as some field studies (see section 5.1) have demonstrated that there is no systematic relationship between fault and dyke swarms. Finally, it is also possible that the 
509

510

511

512

513

514

515

516

517

518

519

520

521

522

523

524

525

526

527

528

529

530

531

532

533

534

535

536

537

538

539

different modes corresponds to different causes, including a mechanical decoupling and also possibly reflecting the intrinsic mechanical properties of the upper levels of the brittle crust.

\section{Conclusion}

(1) Advanced photogrammetric techniques allowed us to accurately map the VFS and differentiate between fissures and faults. We measured the throws of vertical faults with throws greater than $0.5 \mathrm{~m}$ along five of the main fracture zones. By using remote sensing methods we were able to carry out a comprehensive study of the area much more quickly than would have been possible if we had relied solely on field measurements.

(2) The fracturing of the VFS includes both fissures (without vertical throw) and normal faults (with vertical throw), both of which are generally accompanied by opening (from several millimeters to several meters). Most of the fractures are grouped together into main composite lines that generally include both fissures and normal faults. Seven of the normal fault lines are longer than $2500 \mathrm{~m}$. They mostly correspond to the main fault scarps of the fissure swarm. The maximum throw is $\sim 10 \mathrm{~m}$ and seems to be independent of the total length of the fault.

(3) The VFS is an uncommon graben-like structure, bounded to the east and to the west by major normal faults that face west and east, respectively. Faulting deformation between the two boundary faults is mostly accommodated by regularly spaced, west-dipping normal faults. The throws of the boundary and inner faults are not significantly different.

(4) The structure of the fault zone may be closely linked to the network of underlying dikes. When stopped in their progression toward the surface, these dikes may extend upwards as normal faults, which will therefore show similar spacing to the dikes.

(5) In the throw profiles along the fully visible major normal faults, throws are biggest in the central part of the fault segments and decrease towards the segment tips. Composite faults contain several segments. The boundaries between the different segments remain visible for almost the whole growth period.

(6) Detailed analysis of the throw profiles revealed different steps in the fault growth process.

37 The first step is characterized by a moderate increase in throw compared to the increase in

38 length, whereas the second step involves an increase in throw with no or very little increase in length. 
540 (7) The faults in the VFS appear to be very long compared to their throws, suggesting that 541 they may be immature faults with a high potential for further growth. Given the current 542 lengths of the faults, their throws could be expected to increase 3-5 fold without significant 543 lengthening.

544 (8) Analysis of the linkage zones between fault segments revealed a slight but systematic 545 shearing component. This is consistent with the general transform behavior of the Reykjanes 546 Peninsula.

\section{Acknowledgements}

549 We thank Yves Egels for allowing us to use his Poivilliers software for the stereoscopic 550 analysis. Jacques Angelier, Olivier Dauteuil and Guillaume Biessy helped with GCP 551 acquisition. Jacques Angelier also assisted with the production of the photo-mosaics and 552 provided encouragement during the initial stages of the study. We are grateful to Alexandre 553 Lethiers (ISTeP) and André Paillet (Edytem) for their help in drawing the figures. We thank 554 Paul Henderson who read the manuscript and significantly improved our English writing.

555 Águst Guðmundsson and Valerio Acocella are thanked for their helpful reviews and 556 comments. Financial support was provided by the French Polar Institute (IPEV) via Arctic 557 Program 316 IPCROCI.

\section{References}

560 Ackermann, R.W., Schlische, R.W., Withjack, M.O., 2001. The geometric and statistical 561 evolution of normal fault systems: an experimental study of the effects of mechanical layer 562 thickness on scaling laws. Journal of Structural Geology 23, 1803-1819.

563 Acocella, V., Guðmundsson, Á., Funiciello, R., 2000. Interaction and linkage of extension 564 fractures and normal faults: examples from the rift zone of Iceland. Journal of Structural 565 Geology 22, 1233-1246.

566 Acocella, V., Korme, T., Salvini, F., 2003. Formation of normal faults along the axial zone of 567 the Ethiopian Rift. Journal of Structural Geology 25, 503-513.

568 Anders, M.H., Schlische, R.W., 1994. Overlapping faults, intra-basin highs, and the growth of 569 normal faults. Journal of Geology 102, 165-180. 
570 Angelier, J., Bergerat, F., Dauteuil, O., Villemin, T., 1997. Effective tension-shear

571 relationships in extensional fissure swarms, axial rift zone of northeastern Iceland. Journal

572 of Structural Geology 19, 673-685.

573 Árnadóttir, Th., Geirsson, H., Jiang, W., 2008. Crustal deformation in Iceland: Plate spreading 574 and earthquake deformation. Jökull 58, 59-74.

575 Bai, T., Pollard, D.D., 2000. Fracture spacing in layered rocks: a new explanation based on 576 the stress transition. Journal of Structural Geology 22, 43-57.

577 Cartwright, J.A., Trudgill, B.D., Mansfield, C.S., 1995. Fault growth by segment linkage: an 578 explanation for scatter in maximum displacement and trace length data from the 579 Canyonlands Grabens of SE Utah. Journal of Structural Geology 17, 1319-1326.

580 Childs, C., Watterson, J., Walsh, J.J., 1995. Fault overlap zones within developing normal 581 fault systems. Journal Geological Society London 152, 535-549.

582 Childs, C., Nicol, A., Walsh, J.J., Watterson, J., 1996. Growth of vertically segmented normal 583 faults. Journal of Structural Geology 18, 1389-1397.

584 Clifton, A.E., Kattenhorn, S.A., 2006. Structural architecture of a highly oblique divergent 585 plate boundary segment. Tectonophysics 419, 27-40.

586 Clifton, A.E., Pagli, C., Jónsdóttir, J.F., Eythorsdóttir, K., Vogfjörð, K., 2003. Surface effects 587 of triggered fault slip on Reykjanes Peninsula, SW Iceland. Tectonophysics 369, 145-154.

588 Cowie, P.A., Knipe, R.J., Main, I.G., 1996. Introduction to the special issue: Scaling laws for 589 fault and fracture populations, analyses and applications. Journal of Structural Geology 18, $590 \quad \mathrm{~V}-\mathrm{xi}$.

591 Cowie, P.A., Roberts, G.P., 2001. Constraining slip rates and spacings for active normal 592 faults. Journal of Structural Geology 23, 1901-1915.

593 Dauteuil, O., Angelier, J., Bergerat, F., Verrier, S., Villemin, T., 2001. Deformation 594 partitioning inside a fissure swarm of the northern Icelandic rift. Journal of Structural 595 Geology 23, 1359-1372.

596 dePolo, C.M., Clark, G.C., Slemmons, D.B., Ramelli, A.R., 1991. Historical surface faulting 597 in the Basin and Range province, western North America: implications for fault 598 segmentation. Journal of Structural Geology 13, 123-136. 
599 DeMets, C., Gordon, R.G., Argus, F., Stein, S., 1990. Current plate motions. Geophysical 600 Journal International 101, 425-478.

601 DeMets, C., Gordon, R.G., Argus, F., Stein, S., 1994. Effect of recent revisions to the 602 geomagnetic reversal time scale on estimates of current plate motions. Geophysical 603 Research Letters 21, 2191-2194.

604 Einarsson, P., 1991. Earthquakes and present-day tectonism in Iceland. Tectonophysics 189, $605 \quad 261-279$.

606 Forslund, T., Guðmundsson, A., 1991. Crustal spreading due to dikes and faults in southwest 607 Iceland. Journal of Structural Geology 13, 443-457.

608 Friese, N., 2008. Brittle tectonics of the Thingvellir and Hengill volcanic systems, Southwest 609 Iceland: field studies and numerical modelling. Geodinamica Acta 21, 169-185.

610 Geoffroy, L., Dorbath, C., 2008. Deep downward fluid percolation driven by localized crust 611 dilatation in Iceland. Geophysical Research Letters 35, L17302, 612 doi:10.1029/2008GL034514.

613 Grant, J.V., Kattenhorn, S.A., 2004. Evolution of vertical faults at an extensional plate 614 boundary, Southwest Iceland. Journal of Structural Geology 26, 537-557.

615 Guðmundsson, Á., 1980. The Vogar fissure swarm, Reykjanes peninsula, SW Iceland. Jökull $61630,43-64$.

617 Guðmundsson Á., 1986. Mechanical Aspects of Postglacial Volcanism and Tectonics of the 618 Reykjanes Peninsula, Southwest Iceland. Journal of Geophysical Research 91, 12711$619 \quad 12721$

620 Guðmundsson, Á., 1987a. Geometry, formation and development of tectonic fractures on the 621 Reykjanes Peninsula, Southwest Iceland. Tectonophysics 139, 295-308.

622 Guðmundsson, Á., 1987b. Tectonics of the Thingvellir Fissure Swarm, SW Iceland. Journal 623 of Structural Geology 9, 61-69.

624 Guðmundsson, Á., 1992. Formation and growth of normal faults at the divergent plate 625 boundary in Iceland. Terra Nova 4, 464-471.

626 Guðmundsson, Á., 1995a. The geometry and growth of dikes. In: Baer, G., Heimann, A. 627 (Eds.), Physics and Chemistry of Dikes. Balkema, Rotterdam, 23-34. 
628 Guðmundsson, Á., 1995b. Infrastructure and mechanisms of volcanic systems in Iceland.

629 Journal of Volcanology and Geothermal Research 64, 1-22

630 Guðmundsson, Á., 2002. Emplacement and arrest of sheets and dikes in central volcanoes.

631 Journal of Volcanology and Geothermal Research, 116, 279-298.

632 Guðmundsson, Á., 2003. Surface stresses associated with arrested dykes in rift zones.

633 Bulletin of Volcanology 65, 606-618.

634 Guðmundsson, Á., 2011. Rock fractures in geological processes. Cambridge University 635 Press, 578 p.

636 Guðmundsson, Á., Bäckström K., 1991. Structure and development of the Sveinagjá graben, 637 Northeast Iceland. Tectonophysics 200, 111-125.

638 Gupta, A., Scholz, C.H., 2000. A model of normal fault interaction based on observations and 639 theory . Journal of Structural Geology 22, 865-879.

640 Haimson , B.C., Rummel, F., 1982. Hydrofracturing stress measurements in the Iceland 641 research drilling project drill hole at Reyðarfjörður, Iceland. Journal of Geophysical 642 Research 87, 6631-6649.

643 Helgason, J., Zentilli, M., 1985. Field characteristics of laterally emplaced dikes: anatomy of 644 an exhumed Miocene dike swarm in Reydarfjördur, eastern Iceland. Tectonophysics 115, $645 \quad 247-274$.

646 Hjartardóttir, Á. R., Einarsson, P., Sigurdsson, H., 2009. The fissure swarm of the Askja 647 volcanic system along the divergent plate boundary of N Iceland. Bulletin Volcanology 71, $648 \quad 961-975$.

649 Hreinsdóttir, S., Einarsson, P., Sigmundsson, F., 2001. Crustal deformation at the oblique 650 spreading Reykjanes Peninsula, SW Iceland: GPS measurements from 1993 to 1998. 651 Journal of Geophysical Research 106, 13803-13816.

652 Huggins, P., Watterson, J., Walsh, J.J., Childs, C., 1995. Relay zone geometry and 653 displacement transfer between normal faults recorded in coal-mine plans. Journal of 654 Structural Geology 17, 1741-1755.

655 Jóhannesson, H., Sæmundsson, K., 2009. Geological map of Iceland, Bedrock Geology. 656 Icelandic Institute of Natural History, Reykjavik , $1^{\text {st }}$ ed., scale 1:600 000.

657 Kasser, M., Egels, Y., 2001. Digital photogrammetry. Taylor and Francis, London. 
658 Keiding, M., Árnadóttir, T., Sturkell, E., Geirsson, H., Lund, B., 2008. Strain accumulation 659 along an oblique plate boundary: The Reykjanes Peninsula, southwest Iceland, Geophysical 660 Journal International 172, 861 - 872, doi:10.1111/j.1365-246X.2007.03655.x.

661 Keiding, M., Lund, B., Árnadóttir, T., 2009. Earthquakes, stress and strain along an obliquely 662 divergent plate boundary: the Reykjanes Peninsula, southwest Iceland, Journal of 663 Geophysical Research 114, 861-872, B09306, doi: 10.1029/2008JB006253.

664 Mansfield, C. S., Cartwright, J. A., 1996. High resolution fault displacement mapping from 665 three-dimensional seismic data: evidence for dip linkage during fault growth. Journal of 666 Structural Geology 18, 249-263.

667 Marchal, D., Guiraud, M., Rives, T., 2003. Geometric and morphologic evolution of normal 668 fault planes and traces from 2-D to 4-D data. Journal of Structural Geology 25, 135-158.

669 Martel, S.J., Langley, J.S., 2006. Propagation of normal faults to the surface in basalt, Koae 670 fault system, Hawaii. Journal of Structural Geology 28, 2123-2143.

671 Morley, C.K., Nelson, R.A., Patton, T.L., Munn, S.G., 1990. Transfer zones in the East 672 African rift system and their relevance to hydrocarbon exploration in rifts. Bulletin 673 American Association Petroleum Geology 74, 1234-1253.

674 Opheim, J. A., Guðmundsson, Á., 1989. Formation and geometry of fractures, and related 675 volcanism, of the Krafla fissure swarm, northeast Iceland, Bulletin of the Geological 676 Society of America, 101, 1608-1622.

677 Papanikolaou, I.D., Roberts, G.P., 2007. Geometry, kinematics and deformation rates along 678 the active normal fault system in the southern Apennines: Implications for fault growth, 679 Journal of Structural Geology 29, 166-188, doi: 10.1016/j.jsg.2006.07.009.

680 Paquet, F., Dauteuil, O., Hallot, E., Moreau, F., 2007. Tectonics and magma dynamics 681 coupling in a dyke swarm of Iceland, Journal of Structural Geology 29, 1477-1493.

682 Peacock, D.C.P., 1991. Displacements and segment linkage in strike-slip fault zones. Journal 683 of Structural Geology 13, 721-733.

684 Peacock, D.C.P., Parfitt, E.A., 2002. Active relay ramps and normal fault propagation on 685 Kilauea Volcano, Hawaii. Journal of Structural Geology 24, 729-742.

686 Peacock, D.C.P., Zhang, X., 1993. Field examples and numerical modeling of oversteps and 687 bends along normal faults in cross-section. Tectonophysics 234, 147-167. 
688 Peacock, D.C.P., Sanderson D.J., 1991, Displacements, segment linkage and relay ramps in 689 normal fault zones. Journal of Structural Geology 13, 721-733.

690 Roberts, G.P., Michetti, A.M., 2004. Spatial and temporal variations in growth rates along 691 active normal fault systems: an example from The Lazio-Abruzzo Apennines, central Italy. 692 Journal of Structural Geology 26, 339-376.

693 Rowland, J. V., Baker, E., Ebinger, C. J., Keir, D., Kidane, T., Biggs, J., Hayward, N., 694 Wright, T. J., 2007. Fault growth at a nascent slow-spreading ridge: 2005 Dabbahu rifting 695 episode, Afar. Geophysical Journal International 171, 3, 1226-1246.

696 Sæmundsson, K., 1978. Fissure swarms and central volcanoes of the neovolcanic zones in 697 Iceland. In : Bowes, D.R., Leake, B.E. (Eds), Crustal Evolution in Northwestern Britain and 698 Adjacent Regions. Geological Journal Special Issue 10, 415-432.

699 Sæmundsson, K., 1979. Outline of the geology of Iceland. Jökull 29, 7-28.

700 Sæmundsson, K., 1992. Geology of the Thingvallavatn area. Oikos 64, 40-68.

701 Scholz, C. H., 2002. The Mechanics of Earthquakes and Faulting, Cambridge Univ. Press, 702 New York.

703 Schöpfer, M.P.J., Childs, C., Walsh, J.J., 2006. Localisation of normal faults in multilayer 704 sequences. Journal of Structural Geology 28, 816-833.

705 Sonnette, L., Angelier, J., Villemin, T., Bergerat, F., 2010. Faulting and fissuring in active 706 oceanic rift: Surface expression, distribution and tectonic-volcanic interaction in the 707 Thingvellir Fissure Swarm, Iceland. Journal of Structural Geology 32, 407-422.

708 Tentler, T., 2005. Propagation of brittle failure triggered by magma in Iceland. 709 Tectonophysics 406, 17-38.

710 Tentler, T., Mazzoli, S., 2005. Architecture of normal faults in the rift zone of central north 711 Iceland. Journal of Structural Geology 27, 1721-1739.

712 Torabi, A., Berg, S.S., 2011. Scaling of fault attributes: A review. Marine and Petroleum 713 Geology, 28, 1444-1460.

714 Tryggvason, E., 1974. Vertical crustal movement in Iceland. In: Kristjanson, L. (ed), 715 Geodynamics of Iceland and the North Atlantic Area. Reidel, Dordrecht, 241-262. 
716 Tryggvason, E., 1982. Recent ground deformation in continental and oceanic rift zones. In:

717 Pálmason, G. (ed), Continental and Oceanic Rifts. AGU, Washington, Geodynamic Series $718 \quad 8,17-29$.

720 Figure captions

721 Figure 1 - The Vogar Fissure Swarm (VFS) in southwest Iceland. A: The on-land 722 neovolcanic rift in Iceland. The main fissure swarms are shown in grey. EVZ, NVZ and WVZ 723 are the Eastern, Northern and Western Volcanic Zones, respectively. SISZ: South Iceland 724 Seismic Zone. TFZ: Tjörnes Fracture Zone. V: Vatnajökull; B: Location of the four main 725 fissure swarms in the Reykjanes Peninsula, H: Hengill central volcano. C: Schematic tectonic 726 map of the Reykjanes fissure swarm. In light grey: Upper Pleistocene basic and intermediate 727 hyaloclastites and lavas, younger than 0.8 m.yr. In white: Postglacial basic and intermediate 728 lavas, older than AD 871. In dark grey: Postglacial basic and intermediate lavas, younger than 729 AD 871, main normal faults are shown as thin lines with barbs. B and C modified after 730 Sæmundsson (1979), Sæmundsson and Einarsson (1980), Guðmundsson (1986, 1987a), and 731 Jóhannesson and Sæmundsson (2009).

732

733

734 735 736

Figure 2 - Aerial photograph mosaic of the VFS (photographs O8750, O8751 and O8752, 1998, from "Landmælingar Íslands"). All fractures identified in this study are shown as colored lines: East dipping normal faults in blue, with important opening shown in black; west dipping normal faults in green, with important opening shown in yellow; fissures (pure tension fracture) without vertical throw (or vertical throw smaller than $0.5 \mathrm{~m}$ ) in red. Most of these fractures are concentrated within several fracture zones shown in Figure 3. Location grid uses UTM coordinates.

Figure 3 - Main composite fractures of the VFS and location of the along-strike and across-strike profiles. The thick grey lines are the main composite fractures; the black lines are fractures for which we plotted along-strike profiles. Numbers $(\mathrm{R})$ refer to the main composite fractures described in the text. Small arrows numbered 0 to 70 indicate the locations of the across-strike profiles. Blue bands indicate the across-strike profiles shown in Figure 9. The red rectangle shows the location of Figure 11. Rose diagrams show the trends of the 156 individual faults and 322 individual fissures. 
Figure 4 - West-facing, sub-parallel normal fault scarps illustrating the step pattern in the VFS. A: Oblique aerial photograph taken from a helicopter (looking east), B: Detail of two steps (looking southeast).

Figure 5 - A west-facing normal fault with opening in the VFS. The vertical throw is $\sim 2 \mathrm{~m}$. Note the graben-like structure characteristic of near-surface normal faulting (i.e., fault with both vertical and opening components).

Figure 6 - Fissures in the VFS. A: aerial photograph of a long fissure, taken from a helicopter (looking northeast), B: fissure with a small vertical throw (smaller than $0.5 \mathrm{~m}$ ) observable near the photographer, $\mathrm{C}$ : detail of a small fissure opening; part of the fissure follows the columnar joints yielding zigzag geometry.

Figure 7 - Distribution of fracture lengths. Histograms showing the number of fractures $(\mathrm{N})$ as a function of fracture length (L, in meters), with classes of $25 \mathrm{~m}$ for individual fissures (A) and individual faults (B), and with classes of $250 \mathrm{~m}$ for main composite fractures (C).

Figure 8 - Spacing of fractures in the VFS, with number of fractures $(\mathrm{N})$ plotted as a function of spacing ( $\mathrm{S}$, in meters). In blue (lozenges): All individual fractures (fissures and faults). In red (squares): Individual fissures. In green (triangles): Main composite faults.

Figure 9 - Changes in the topography across the VFS. Sections 23-27 and 50-54 as examples (see location in Figure 3). The number of main composite fractures cut by the profiles is indicated. Lengths and altitudes are in meters. A-D profiles are enlargements of fault scarps R16 and R28, which face east and west, respectively.

Figure 10 - Along-strike changes in fault throw for main composite fractures R16, R24 R28, R38 and R48 (see location in Figure 3). All throws and distances are in meters. Throw profile established from the along-strike topographic profiles at a distance of $20 \mathrm{~m}$ from the main discontinuity are shown as black lines, and at a distance of $40 \mathrm{~m}$ are shown as grey lines.

Figure 11 - Detailed view of the central part of fracture R38 and its junction with fracture R36 (mosaic of a dozen oblique aerial photographs taken from a helicopter). Note the smaller shadow of fault R38 in the left-hand two thirds of the mosaic, indicating a decrease in its throw (here, the deformation is accommodated by R38 and by R36, which are parallel, see location in Figure 3). 
Figure 12 - Fault tips and fault linkages at the surface (aerial photographs taken from

778 a helicopter). (a) Non-overlapping close segments. (b) Non-overlapping segments with 779 oblique fracture forming the junction. (c) Poorly overlapping segments with each tip 780 propagating to the sidewall of the other segment. (d) Horsetail-type tip of a fault segment in 781 the linkage zone with another segment. (e) Amply overlapping sub-parallel close segments.

782 (f) Non-overlapping segment with sub-parallel en-echelon fractures forming the junction. (g) 783 Complex linkage zone including oblique and sub-parallel fractures. (h) Detail of the horsetail 784 tip of a fault.

785 Figure 13 - Immature and mature junctions between fault traces. It is possible to pass 786 from one side to the other of an immature fault without crossing any fractures (as shown by 787 the dotted line). In the mature state, the two fault segments are connected and the two sides of 788 the fault are fully separated.

789 Figure 14 - Conceptual model of fault growth in the VFS (adapted from Cowie and 790 Roberts, 2001; Roberts and Michetti, 2004; Papanikolaou and Roberts, 2007). (a) Model of 791 throw-fault length profile. Fault segments initially grow by increasing in length and in throw 792 (stage 1). At the end of stage 1, fault linkage occurs and fault segments interact over long 793 distances (stage 2). (b) Graph showing throw as a function of time for the central segment 794 shown in (a). This illustrates the throw enhancement rate as interaction and linkage proceed. 795 See text for a detailed explanation. SB: Segment boundary, d1: Maximum throw on each 796 segment prior to linkage, d2: Maximum throw on the entire fault after linkage, L1: Length of 797 a single segment, L2: Length of the fault after linkage. 


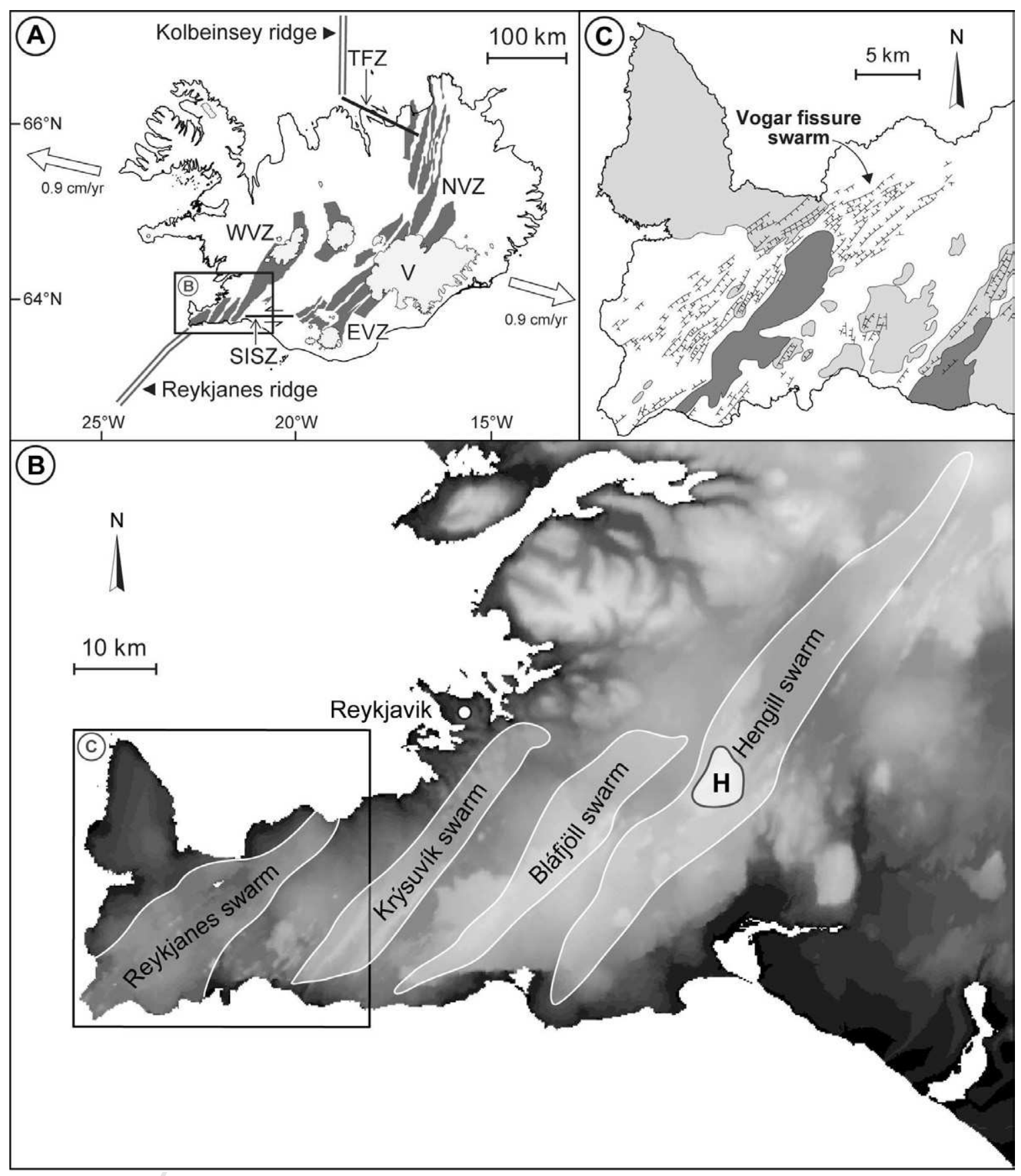




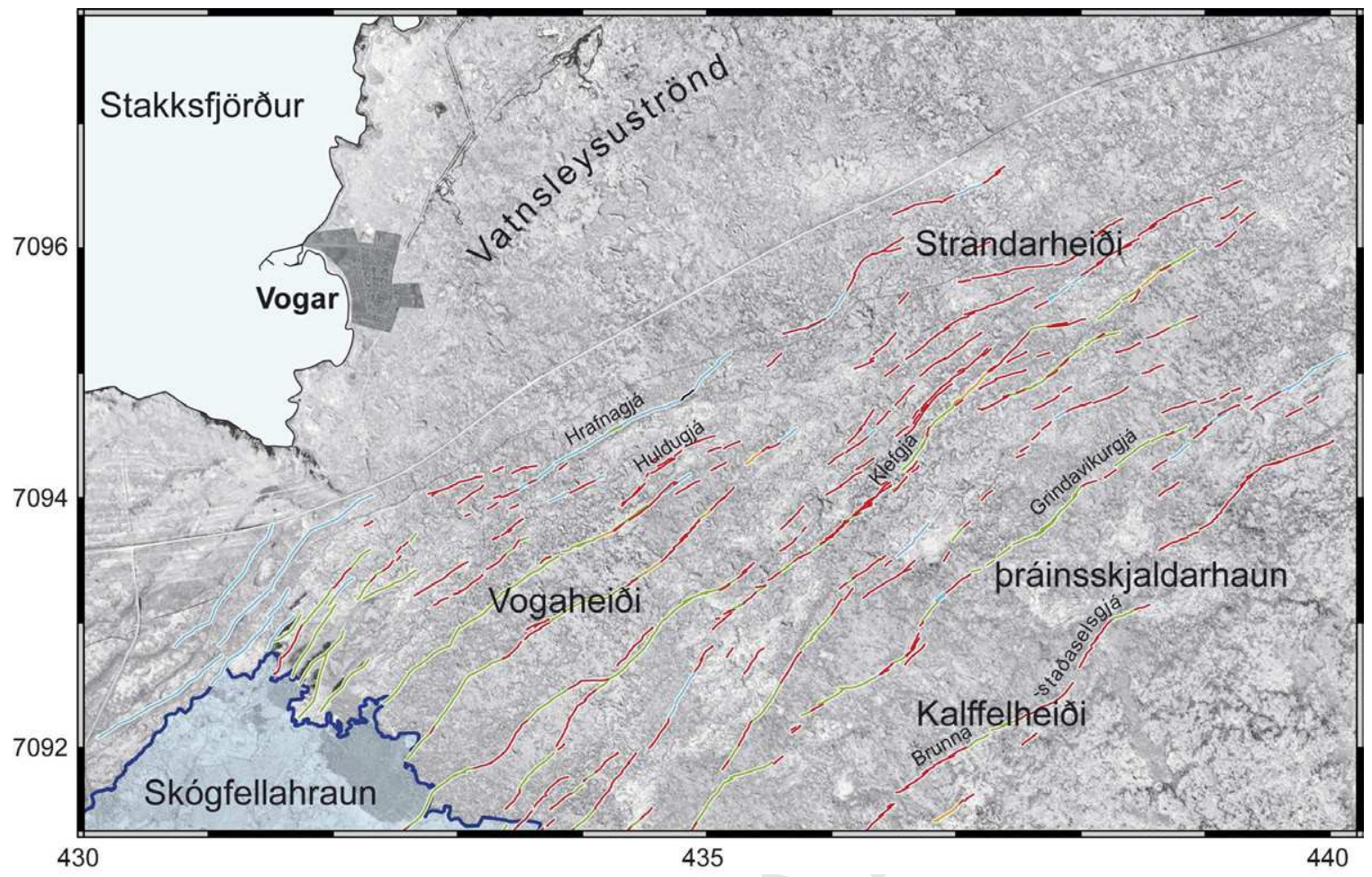




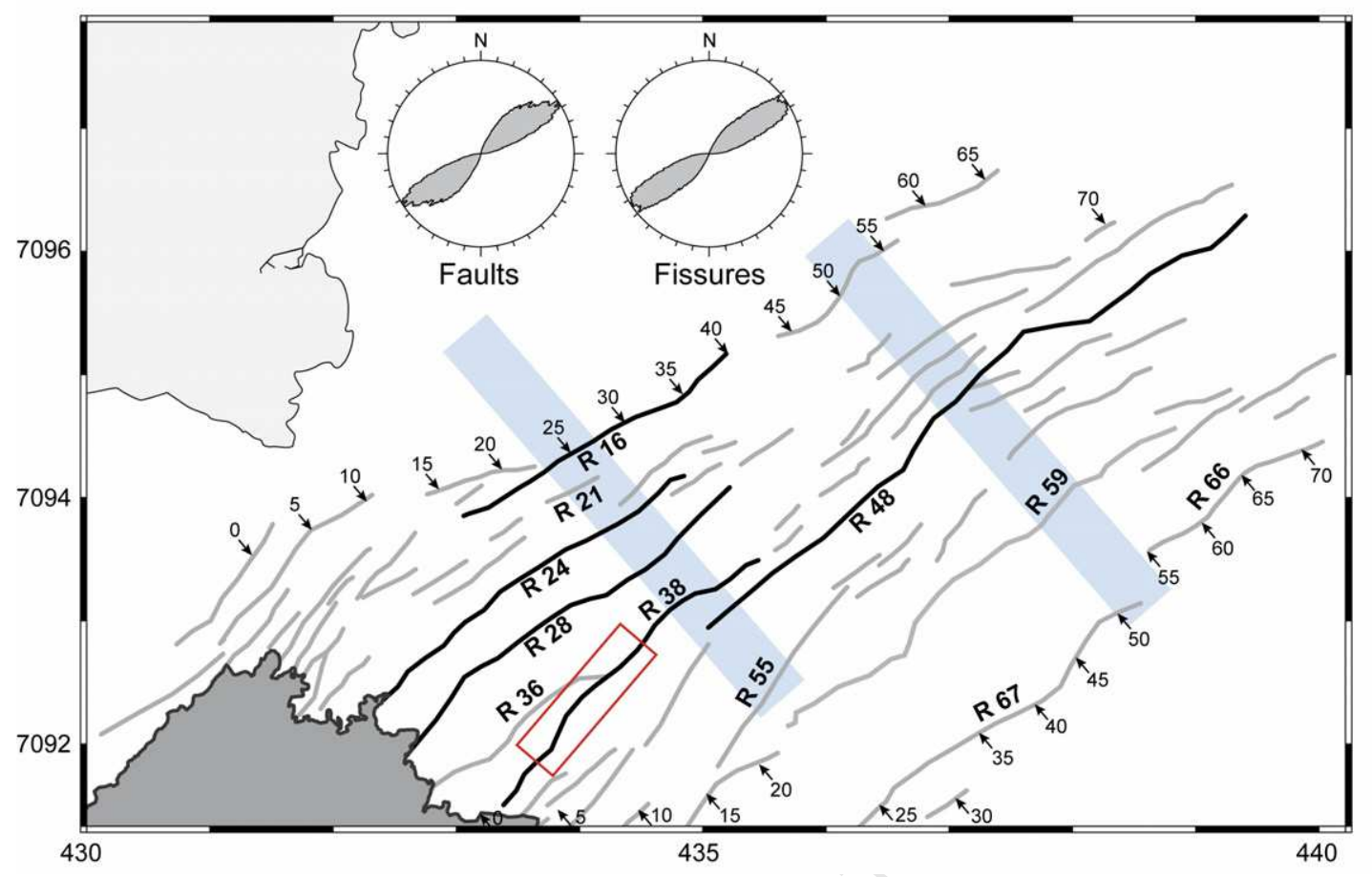



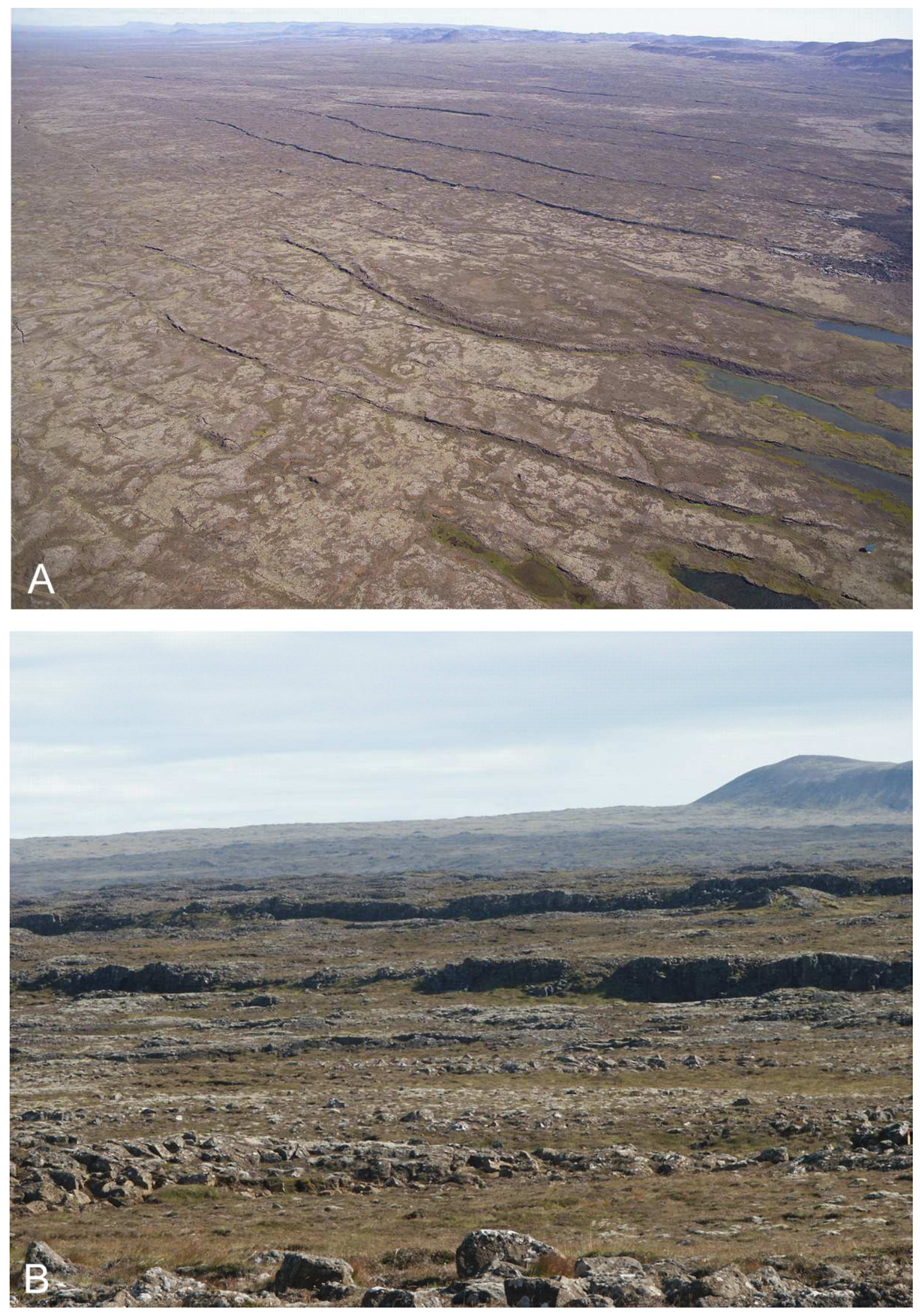


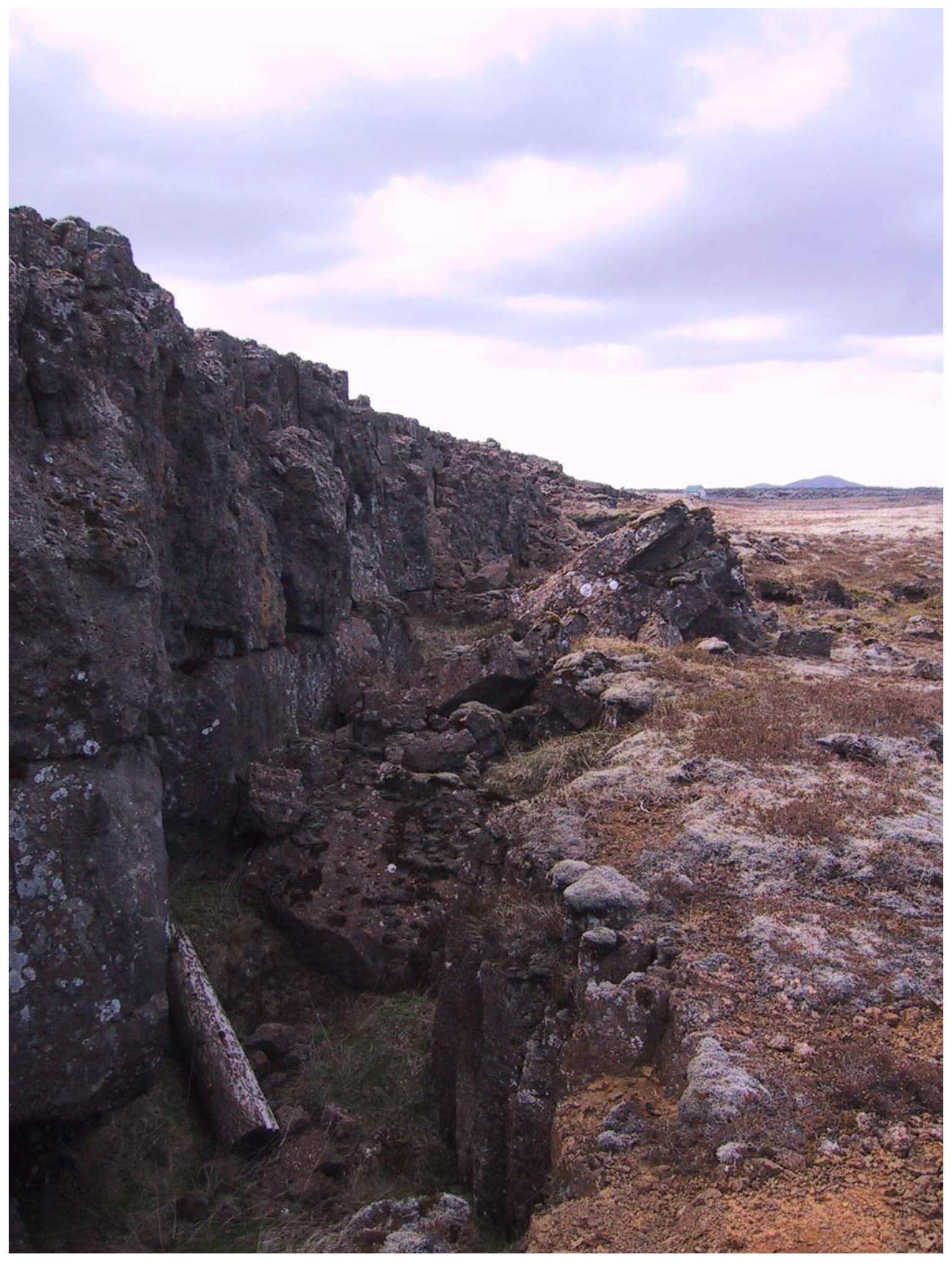



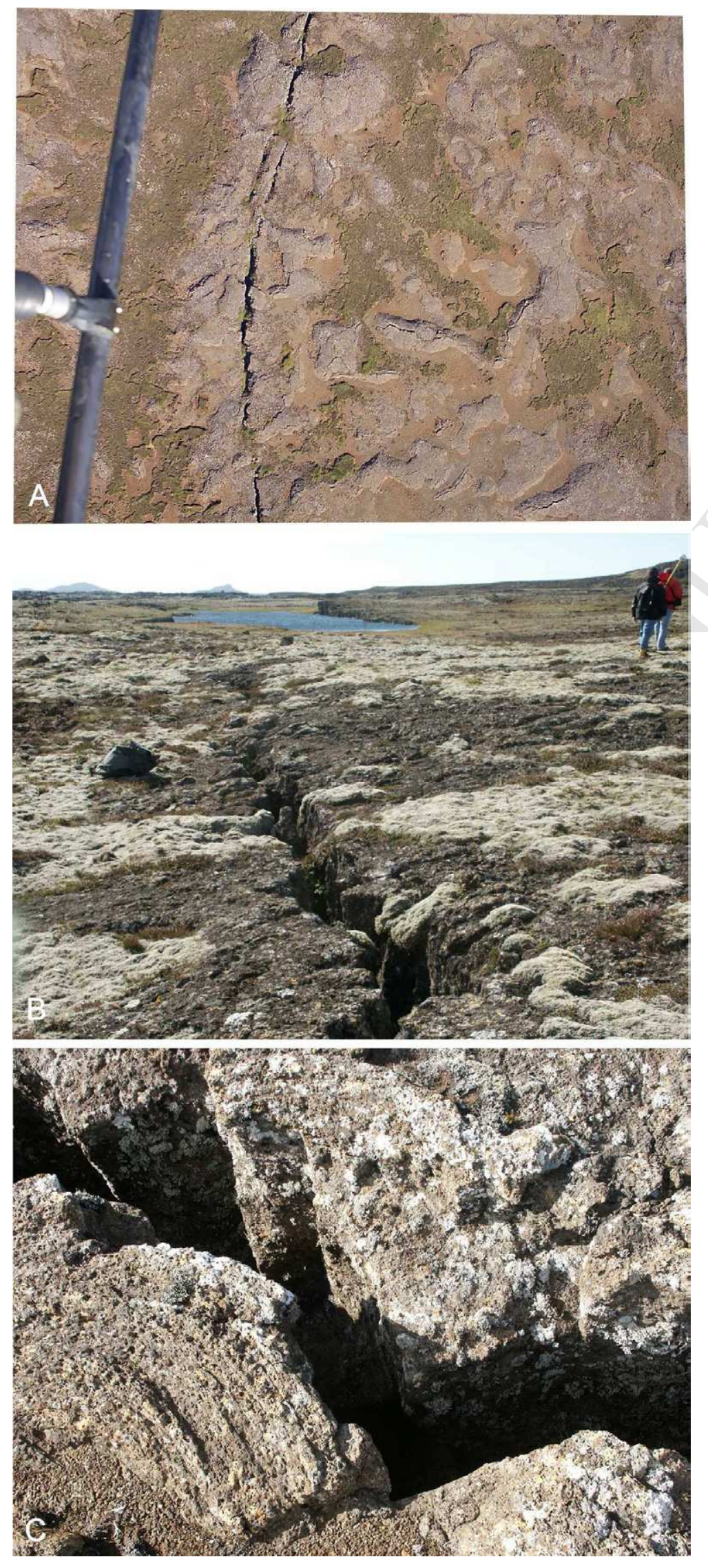
ACCEPTED MANUSCRIPT
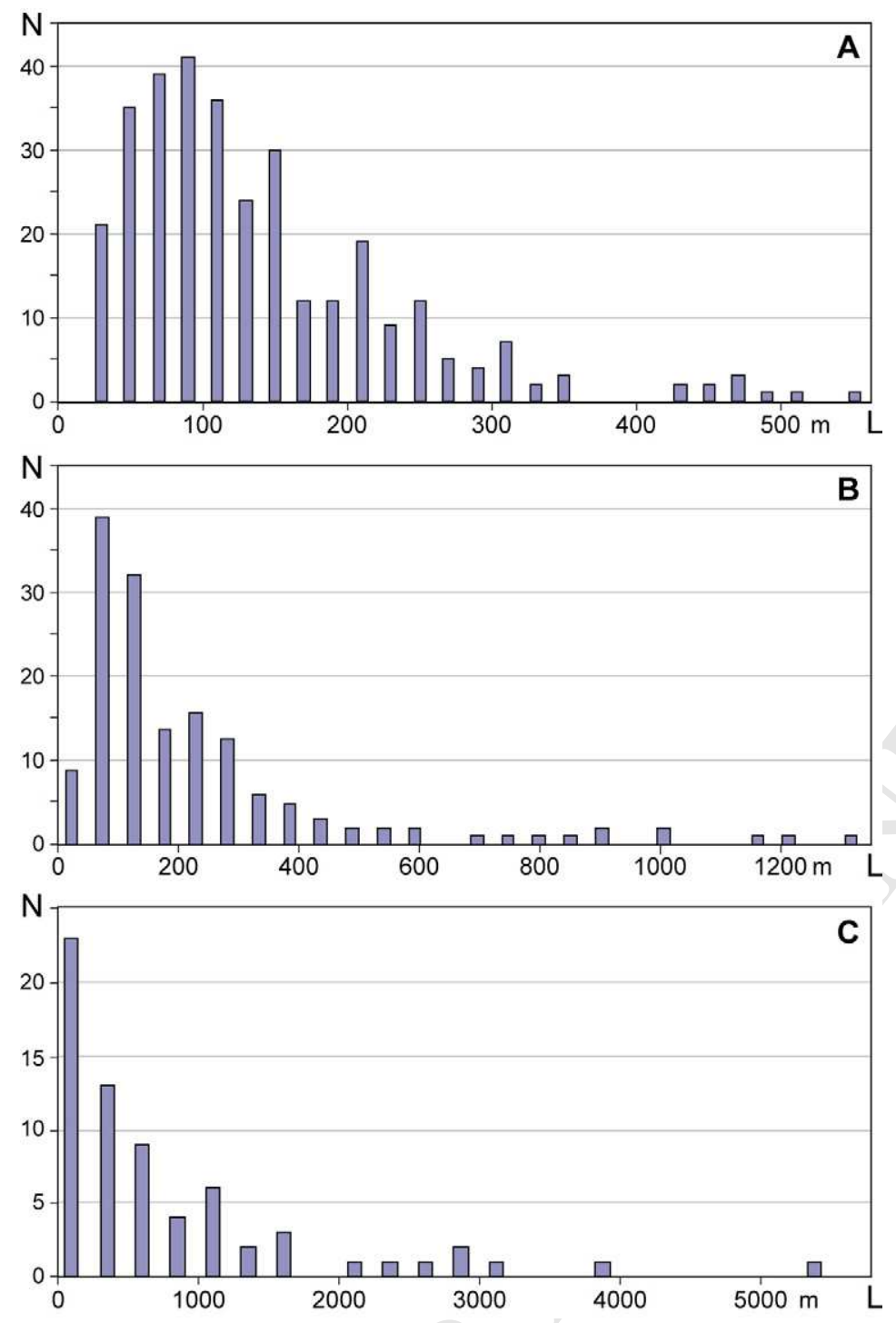


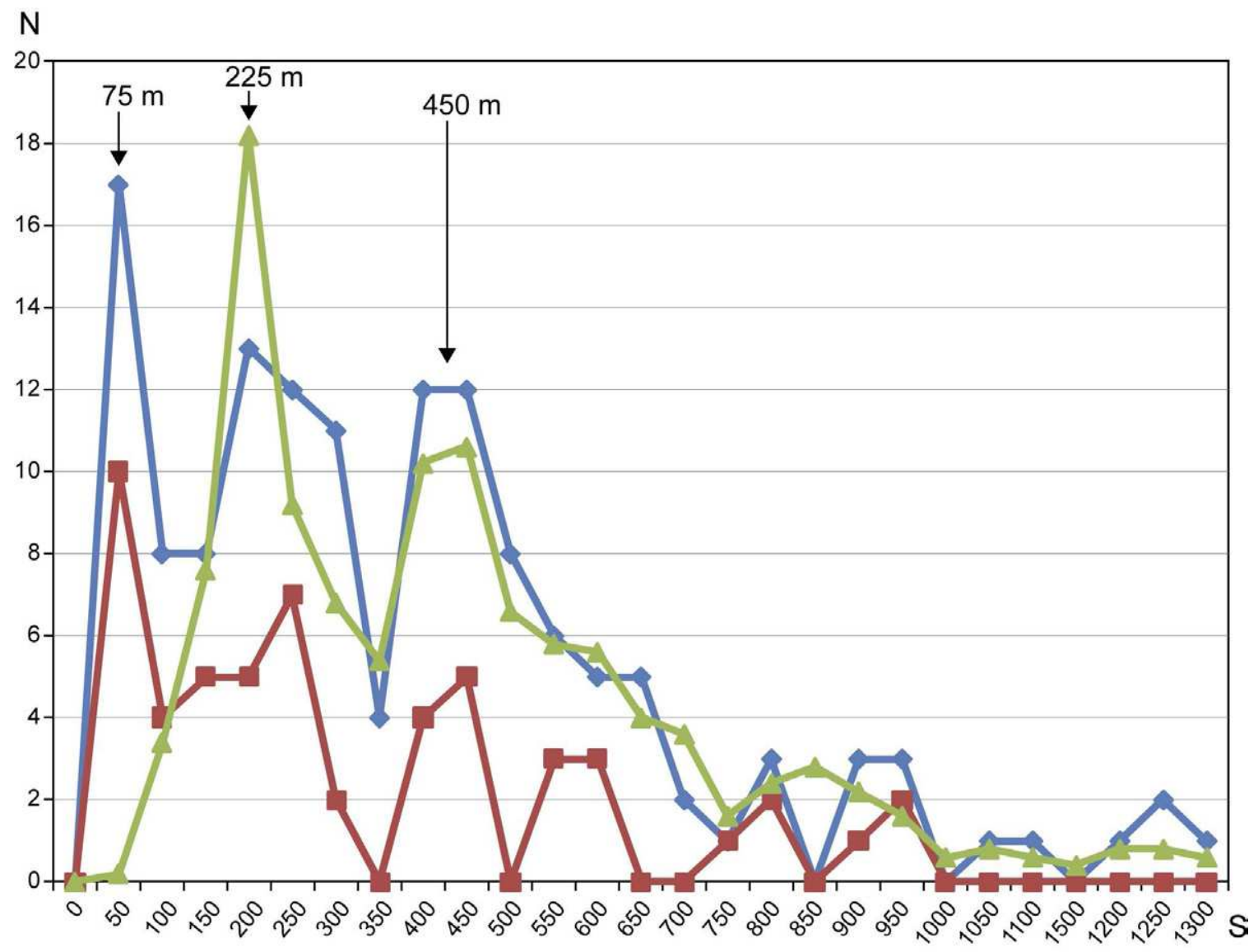



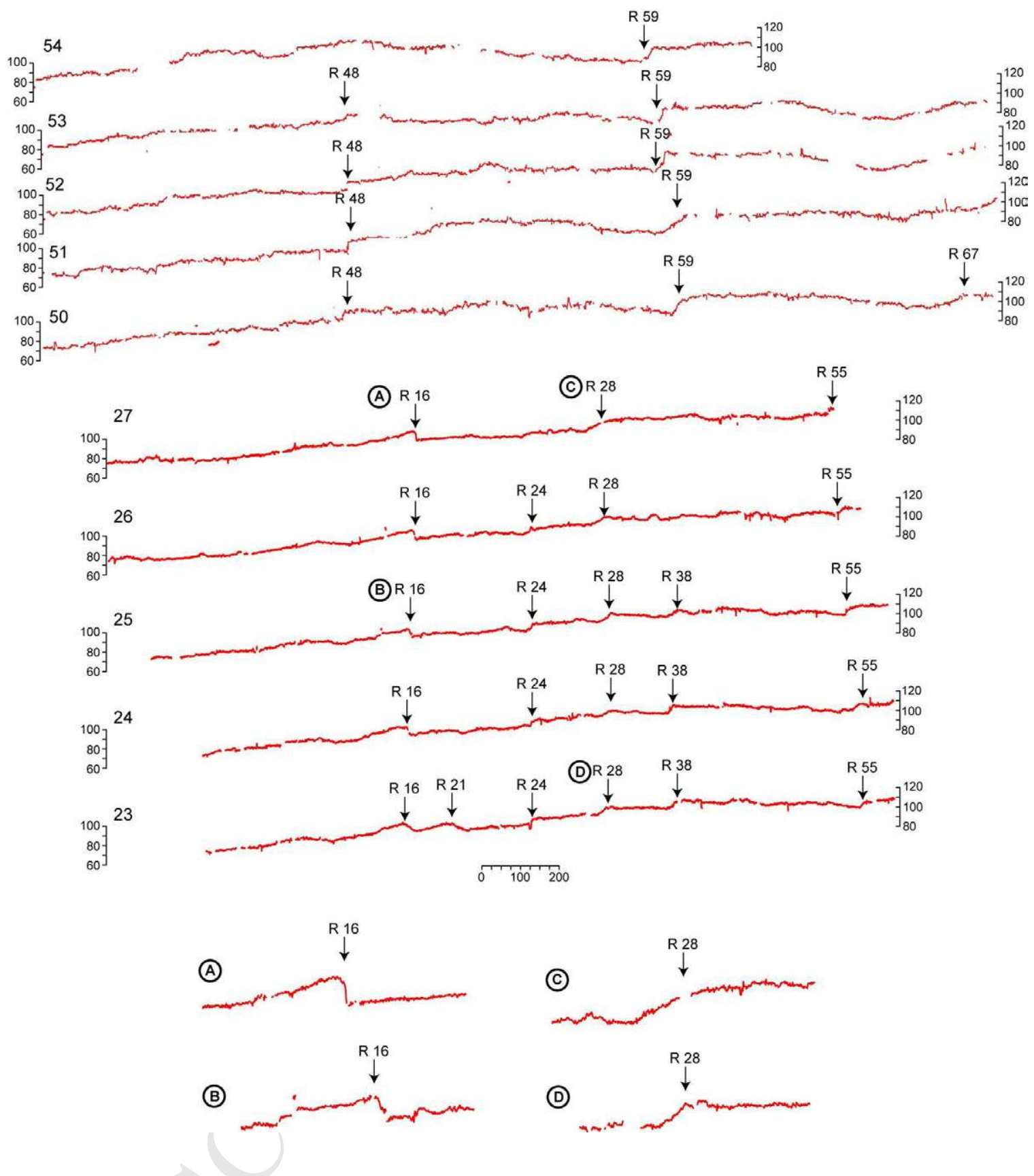


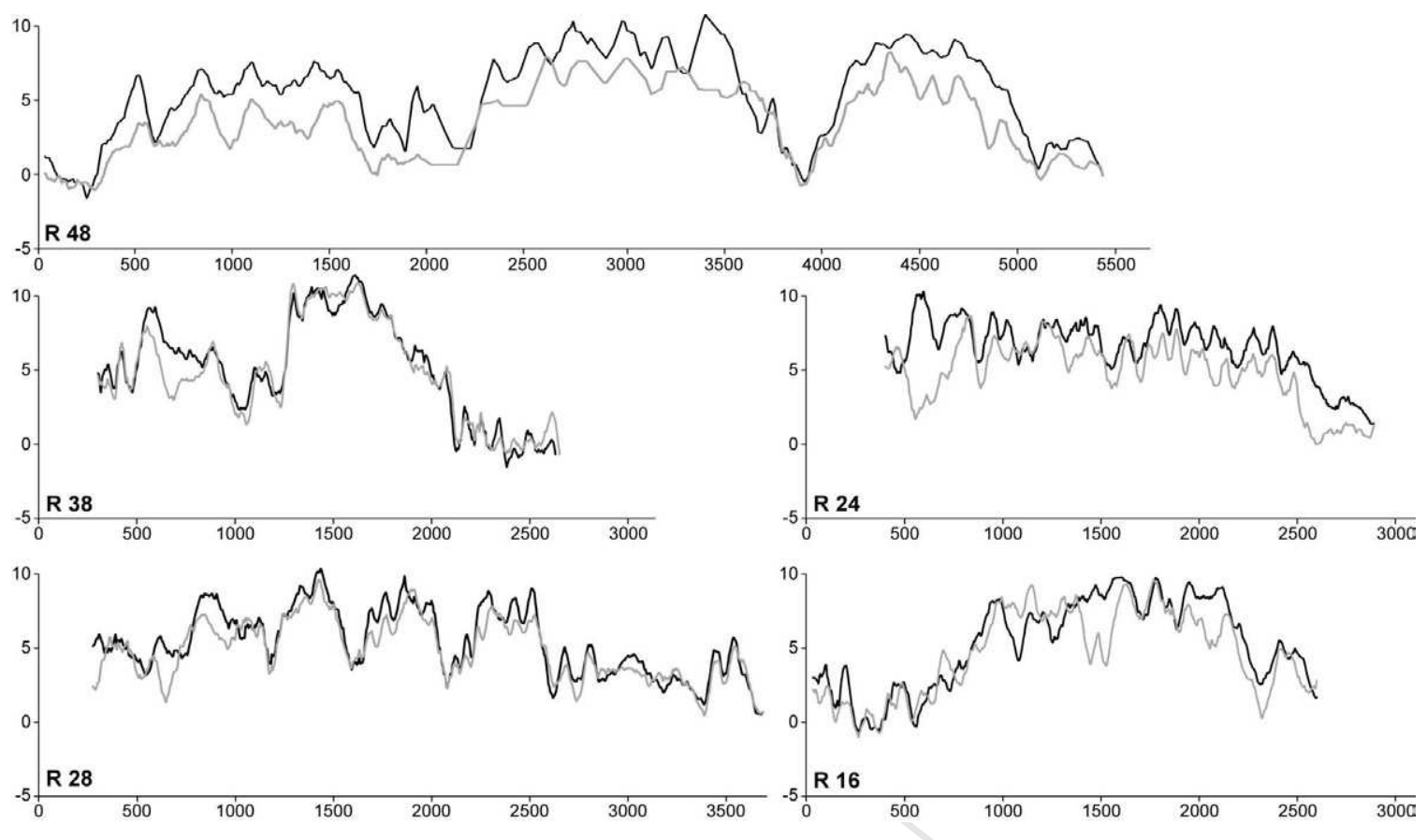




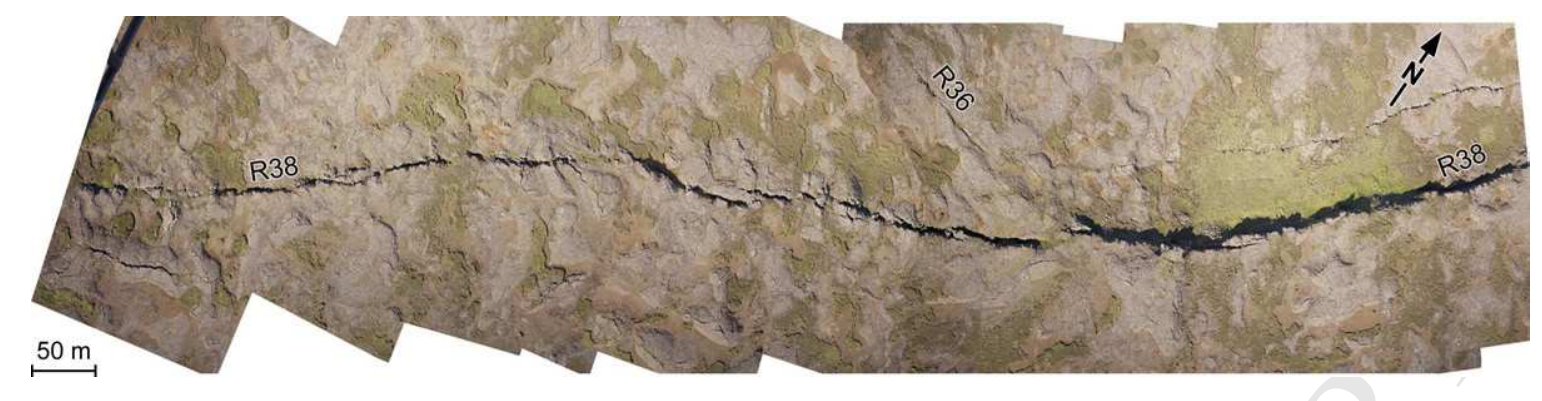



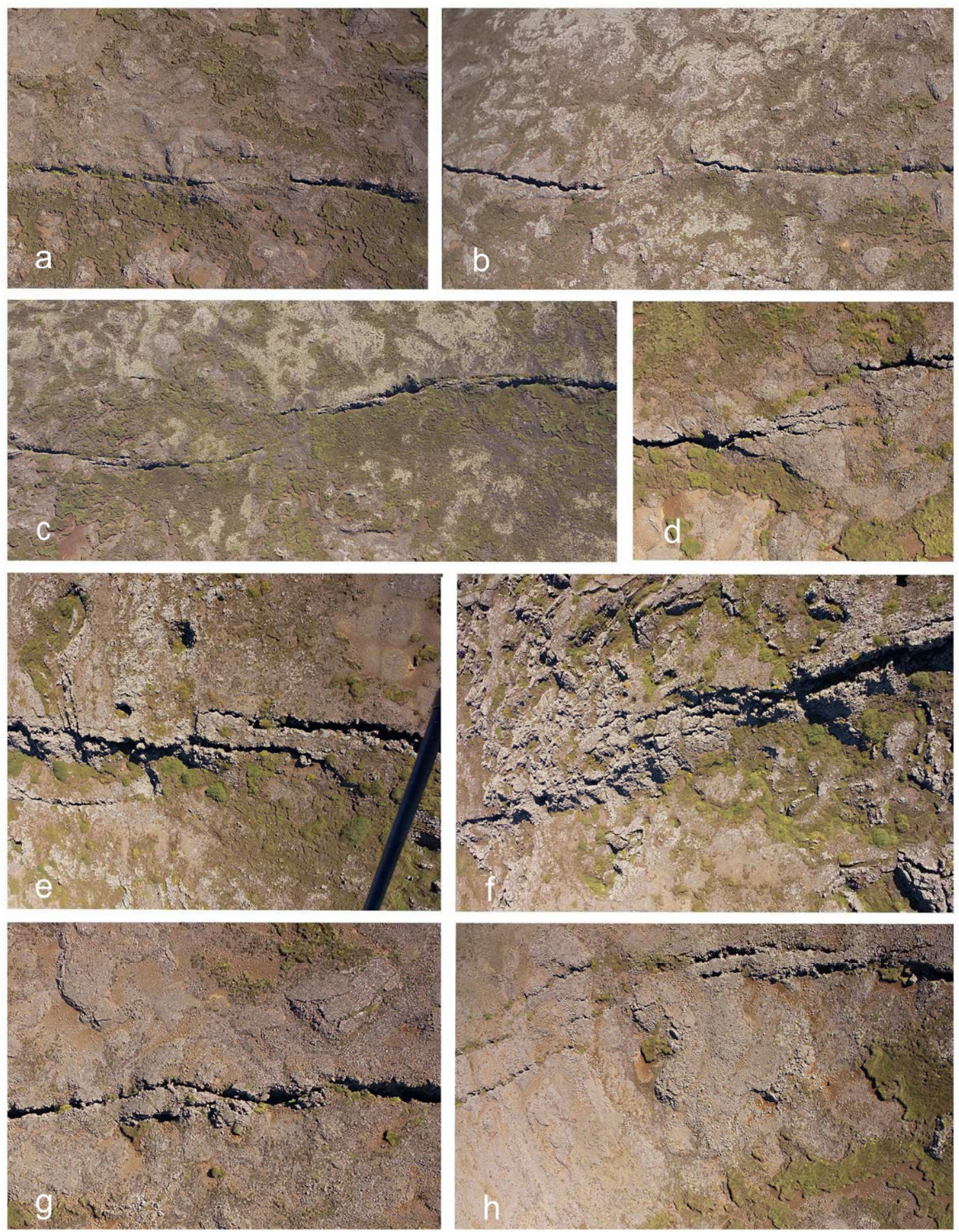


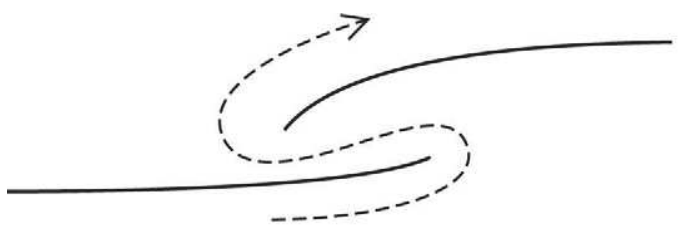

Immature stage

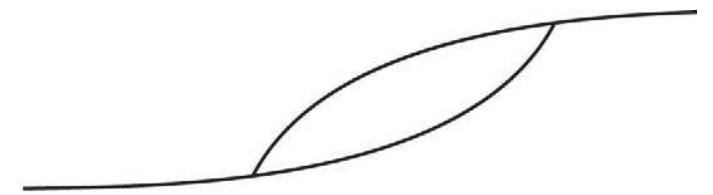

Mature stage 

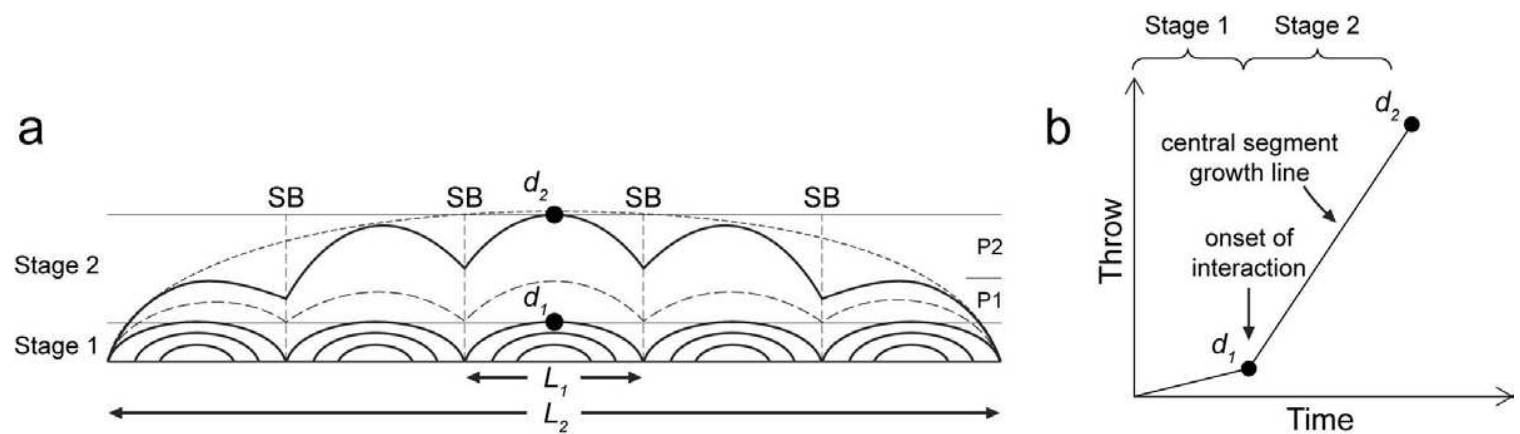